\title{
Aging: Thromboembolic Disease, Metabolic Syndrome, Type 2 Diabetes Mellitus, and Alzheimer's Disease
}

\author{
Joaquín Lasierra-Cirujeda1*, María José Aza Pascual-Salcedo², Alicia Lasierra-Ibañez1, \\ Carmen Lasala Aza ${ }^{1}$, María Mercedes Aza Pascual-Salcedo ${ }^{3}$ \\ ${ }^{1}$ Centro Médico Hematológico, Logroño, Spain \\ ${ }^{2}$ Pharmaceutical Act Ministry of Health, La Rioja Regional Government, Logroño, Spain \\ ${ }^{3}$ Aragon Health Service, Zaragoza, Spain \\ Email: "hematol@telefonica.net
}

Received 25 March 2016; accepted 7 May 2016; published 10 May 2016

Copyright (C) 2016 by authors and Scientific Research Publishing Inc.

This work is licensed under the Creative Commons Attribution International License (CC BY).

http://creativecommons.org/licenses/by/4.0/

(c) (i) Open Access

\begin{abstract}
Aging can be interpreted as an unavoidable process whose end point is the death. Aging entails, in the hemostasis field, some changes that favour blood hypercoagulability. Both the plasminogen activator inhibitor (PAI-1), specific inhibitor of the tissue plasminogen activator (t-PA), accompanied by the oxidative stress and the marked decrease of the main antioxidant-glutathione are fundamental in the bases of elderly pathologies which can cause death. There is some scientific evidence of the relationship between aging, neuro-degenerative diseases, an excessive production of reactive oxygen species and the decrease of proteolysis in brain. The cerebral plasminogen/plasmin system represents the essential proteolytic mechanism that degrades amyloid peptides $(\beta$ amyloidosis) for action of plasmin with effectiveness. This physiologic process is being considered as a preventive neurodegenerative mechanism. At the same time, the decrease of glutathione levels in aging entails a decrease of cerebral plasmin activity and a progressive descent of $t-P A$ activity due to a descent in t-PA expression and an increase in PAI production. All of them entail an increment of amyloid beta peptides $(A \beta)$ production and a lower level of their clearance. Both mechanisms, oxidative stress, direct consequence of the oxygenate metabolism of aerobics cells, and changes in the systemic fibrinolysis and cerebral $b$-amyloidolytic activity, play a very important role in thromboembolic disease, metabolic syndrome-obesity, insulin resistance, hyperglycemia-, type 2 Diabetes Mellitus and Alzheimer's disease, clinical processes that accompany the aging. In this revision we show the importance of the interaction between glutathione, proteolytic t-PA/plasminogen/plasmin system, and the inhibitor PAI-1 in aging physiopathology, whose results suggest the hypothesis of the importance of a therapeutic strategy using the inhibition of
\end{abstract}

${ }^{*}$ Corresponding author.

How to cite this paper: Lasierra-Cirujeda, J., Aza Pascual-Salcedo, M.J., Lasierra-Ibañez, A., Lasala Aza, C., Aza Pascual-Salcedo, M.M. (2016) Aging: Thromboembolic Disease, Metabolic Syndrome, Type 2 Diabetes Mellitus, and Alzheimer's Disease. Journal of Biosciences and Medicines, 4, 1-20. http://dx.doi.org/10.4236/jbm.2016.45001 
PAI-1 as a goal, because it is increased in the different aging pathologic processes.

Keywords

Aging, Alzheimer's Disease, T2DM, PAI-1, Glutathione

\section{Introduction}

Aging can be interpreted as an unavoidable process whose end point is the death. Longevity, consequence of an improvement of environmental, social, sanitary conditions and of quality of life along the XX century involves a morbidity and mortality reduction with an increment in the life expectancy [1]-[3]. There is some scientific evidence that $27.6 \%$ of European population will be 65 or more years by 2050 [4]. This longevity has created a centennial society with a less burden of disease that frequently appears in the development of aging and often causes death of younger people [5].

There are many definitions of aging. It is possible that it refers to a normal process, as a consequence of organism metabolism with a formation of toxic substances that damage cellular structures, proteins and nucleic acids, explains the most frequent pathologies in the senility and could be considered the most right one.

Among the substances that modify the normal physiologic operation, oxidative stress-direct consequence of the oxygenate metabolism of the aerobic cells [6]-[10], hemostatic changes in systemic fibrinolytic mechanism, changes in cerebral b-amyloidolytic mechanism, an increase in the expression of plasminogen activator inhibitor (PAI-1) - main inhibitor of the tissue plasminogen activator (t-PA) [11]-[13], play a very important role in the thromboembolic disease, metabolic syndrome (MS), (obesity, hyperglycemia, insulin resistance (IR)), type 2 Diabetes Mellitus (T2DM) and Alzheimer's disease (AD). These diseases are associated to clinical processes with glutathione (GSH) depletion and oxidative stress that accompany the aging. According to epidemiologic and pathogenic studies, these entities possibly share physiopathological factors as much in their progression as in their etiology [14]-[21].

In this study, we focus on the clinical importance of the pathogenic processes, such as obesity, type 2 Diabetes Mellitus, metabolic syndrome, Alzheimer's disease and thromboembolic disease, because of their prevalence in the aging, and because all of them have a glutathione depletion [22] [23] and an increment of PAI-1 expression [11] [13] [24] [25]. Glutathione is the most important antioxidant in aging, and PAI-1 is the main inhibitor of tissue plasminogen activator. For this reason, an increment of glutathione or a reduction of PA1-1 could be a useful way to prevent these diseases which accompany the aging process.

\section{Thromboembolic Disease and Aging}

An increment of the venous and arterial thromboembolic diseases has been observed in aging [26]-[30]. It is though that it can be attributed to fibrinogen, factor VIII and factor IX increments, molecular and anatomical changes of vascular wall and an increase of platelet activity. In fact, a state prothrombotic is created as shows the hypercoagulability found in blood [26]-[28] [31]-[35]. Nevertheless, in spite of the great activity or concentration of some blood clotting factors, the high incidence of thromboembolic diseases in aging can be related to the decrease of systemic fibrinolytic activity [26] [27] [33]-[37]. The study of the different components of fibrinolytic system in aging shows an increase of t-PA antigen with a marked depletion of its activity (t-PA) and an increase of PAI-1. It is suggested that the tendency of diminishing the t-PA activity for their inhibitor PAI-1 can be related with the increase of thrombosis incidence in the elderly [14] [37]. The potent inhibitor PAI-1 is not only increased in aging but it is also enhanced, in a significant way, in the pathogenesis of processes very related to aging, such as myocardial infarction, atherosclerosis, thromboembolic disease, MS (obesity, RI, hyperglycemia), T2DM and neurodegenerative diseases including AD and Parkinson disease (PD). These processes are accompanied by oxidative stress and an enhanced production of reactive oxygen species (ROS) with marked decrease of GSH [19] [38]-[47], by an impaired fibrinolysis due to elevated PAI-1 levels, principal regulator of fibrinolysis [48] [49], a descent in t-PA activity as answer to a GSH decrease [50] and they could play a very important role in the pathogenesis of thrombotic disorders in the MS in the elderly [12]. 


\section{Systemic and Cerebral Glutathione System in Aging}

GSH is the most abundant non-protein thiol in mammal cells, being mainly located in mitochondria, nucleus and endoplasmic reticule and in a very low concentration in extracellular spaces [51] [52]. GSH synthesis is generated in two steps: the first one is the combination of cysteine with glutamate in presence of ATP and $\gamma$-glutamylcysteine synthetase enzyme to form glutamylcysteine. The second one is the combination with glycine to produce GSH (gamma-glutamyl-cysteinyl-glycine) [53]-[55].

ROS are generated continuously during oxidative metabolism. GSH system is fundamental for cellular defence against ROS. A GSH decrease or a ROS increase cause oxidative stress and metabolic alterations. The GSH anti-oxidant action stands out among its multiple physiologic activities. It is due to its capacity of neutralize free radicals. GSH deficit involves oxidative stress [51] [52] [55]-[64] and it has been suggested that GSH plays a role in the apoptosis regulation [65]. High GSH concentrations are associated to high levels of physical health [66].

There is some scientific evidence of a GSH reduction in aging and a decrease of gamma-glutamylcysteine synthetase gene [67] [68] in some age-related diseases. It makes the organism be more vulnerable to oxidative stress. An increment of free radicals causes harmful effects in many chronic pathologies in the elderly [52] [64] [66] [68]-[78]. The decreased GSH levels in the healthy elderly predispose them to suffer metabolic alterations, detoxification mediated by GSH [71], a decreased proteasomal activity [63] [79]-[81], mitochondrial alterations [82], a ROS increase [83] and a great quantity of clinical entities in the field of the medical pathology [66] [84] [85].

GSH system in brain is the most important component of the anti-oxidant mechanism in chronic pathological entities associated with aging [76] [83] and it develops a fundamental role in xenobiotic detoxification "in situ" within the central nervous system [86]. The high cell specialization confers a significant capacity to generate free radicals on human brain as consequence of high oxygen requirement, $20 \%$ of the total consumption of the organism, in spite of being less than $2 \%$ of the body weight in adults [87].

Astrocytes and neurons maintain a cellular language in a very specific way about GSH neuronal synthesis and brain protection against oxidative stress [76]. In this line, neurons are considered to contain less GSH than astroglial cells [76] [88]. Nevertheless, the concentration varies with the region from which the cells have been prepared. In cortex cultures, neurons contain less GSH than astroglial cultures [89]. Nevertheless, neurons maintain GSH levels taking up cysteine provided by glial cells [90]-[92] being astrocytes the main GSH supplier to microglia and neurons in the brain [93].

A GSH deficit is observed in neurodegenerative diseases, mainly AD and PD [64] [77] [84] [94]-[99], obesity, MS and T2DM [74] [85] [100]-[102]. It is important to indicate that GSH deficit by pharmacological synthesis inhibition with buthionine sulfoximine (BSO) or diethyl maleate in animal models involves an inhibition of systemic fibrinolytic activity with a marked decrease of t-PA and an increase of PAI-1 [13] [50] [58]. Thus, PAI-1 would play an important role in aging pathology, cardiovascular diseases, thromboembolic diseases, and in systemic vascular atherothrombotic and cerebral complications, which are so frequent and cause death.

\section{Metabolic Syndrome}

MS is a group of physical and metabolic abnormalities. It is a clinical complex process characterized by an alteration of glucose metabolism, an increase of blood pressure and a deposit of abdominal fat, finding a defined group of risk factors such as hyperglycemia, IR, low HDL levels, and high LDL levels. It is associated with an increased cardiovascular morbidity and mortality, even in absence of baseline cardiovascular disease or diabetes [103] [104] and their treatment and prevention are their primary medical care [105].

Likewise, there is some evidence that a higher prevalence of MS [106] and higher PAI-1 concentrations [107] in male patients with depression symptoms. It has been well documented that android obesity, the most important factor in SM [108] [109] increases the risk of venous thromboembolism, atherothrombotic disease, cardiovascular disease, stroke, T2DM, and AD [22] [103] [105] [110]-[122]. MS is associated with hypofibrinolysis, with a decreased plasmin activity by increased PAI-1 levels [123]-[129].

Although MS is a complex process, there are some in vitro and in vivo studies that show PAI-1 can be involved in the metabolic process of the obesity [127] [130] [131], causing thrombotic events in obese people [11] [12] [132] [133].

Obesity has been considered as the central factor of MS [115], and it is associated with a decrease of fibrino- 
lytic activity by a very significant increment of PAI-1 [126] [130] [134]-[136], the main t-PA inhibitor and a well-known risk factor for venous thrombotic or arterial complications [133] [137]. In this line, obesity and PAI-1 are considered as risk factors of cardiovascular illnesses and they play a very important role in the development of the atherothrombosis associated with impaired fibrinolysis [123] [126] [134] [138]-[140].

At experimental level, high PAI-1 levels have been observed in adipose tissue in mice as well as in obese animals [132] [141] [142]. Although the main sources of plasma PAI-1 are liver, endothelial cells and thrombocytes [143] [144], some studies in human adipose tissue put in evidence that adipocytes are a source of PAI-1. Therefore, adipose tissue may directly contribute to increase circulating PAI-1 levels in human [123] [126] [130] [145]-[149]. Likewise, at experimental level it has been observed that PAI-1 inhibitors can neutralize the increment of PAI-1 in pre-adipocyte cultivations [150].

IR is another metabolic factor of MS and it represents an inductor factor of T2DM and it is associated with the oxidative stress process [151] [152]. IR can precede the beginning of T2DM for years [153] [154]. There is some scientific evidence of the probable association between neurodegeneration and IR [111]. SM is closely related to T2DM. RI, a risk metabolic factor of SM and a hallmark of T2DM, it is also expressed in AD [155] and it is considered the major regulator of PAI-1 expression, a common denominator in the physiopathology of these processes [155]. In diet-induced IR, IR promotes amyloidogenic beta-amyloid $\mathrm{A} \beta$ 1-40 and $\mathrm{A} \beta$ 1-42 peptide generation and a production of amyloid plaques in the brain of mice Tg2576 [156] [157]. IR reduces the clearing of $\mathrm{A} \beta$ through descending the insulin-degrading enzyme expression, increasing $\mathrm{A} \beta$ deposits in $\mathrm{AD}$ models [156]-[158]. IR is associated to an increase of development of cardiovascular illnesses [159]-[161] strongly related to a decreased fibrinolytic activity due to a marked increase of PAI-1 [22] [38] [128] [162]-[167].

\section{Type 2 Diabetes Mellitus and Alzheimer's Disease}

T2DM and AD are the two clinical processes more prevalent in aging. Along more than 20 years T2DM is being discussed to be an AD risk clinical factor. Prospective studies carried out in Rotterdam Study [168], Rochester (Minnesota) [169], Rotterdam [170], and Estokolmo [171], revealed an increased dementia risk in people with T2DM. Community multi-ethnic studies report a weak association between diabetes and AD and a strong association between diabetes and stroke-associated-dementia. It was significantly higher in Blacks and Hispanics than in Whites [113]. In another study, the Honolulu-Asia-Aging Study, diabetes was associated with vascular dementia and AD in Japanese American men. There was a particularly strong association between diabetes and $\mathrm{AD}$ in people who carrier apolipoprotein E (APOE) $\varepsilon 4$ allele [114]. Finally, a systematic review and a metaanalysis with 15 epidemiology studies report positive association between T2DM and AD [172].

Although the nature of the association is not yet known, it is interesting to point out that multiple common features of clinical processes that accompany the aging can influence the relationship between T2DM and AD [153] [172]-[174]. The association between diabetes mellitus and impaired cognitive function suggests that diabetes mellitus may contribute to increase the development of dementia rate in AD two to three times [175]. T2DM is associated with a decreased cognitive function in adults and the elderly [169] [176]-[183]. The insulin receptor insulin/insulin-like growth factor-1 might represent a molecular link between T2DM and AD [184]. Likewise, an interrelation among these two clinical entities has been suggested by the following reasons: the risk of developing the both processes in aging, its association with APOE, tau formation, oxidative stress, a decrease of glutathione concentration, IR, hyperinsulinemia, alterations of both systems: insulin growth factors and transforming growth factors, hyperphosphorization of tau protein, amyloid- $\beta$ deposition, hypo-proteolysis, elevated PAI-1, stroke and brain atrophy [18] [111] [114] [168]-[170] [185]-[197]. Likewise, in relation to metabolic alterations in T2DM, they are an impaired glucose tolerance and hyperinsulinemia in brain AD, and for this reason some researchers refer to AD as the type 3 diabetes [198]-[204].

In recent years, some scientific evidence supports the concept that $\mathrm{AD}$ is a metabolic disease as result of the inability of the use of glucose and IR in brain, characterizing AD as brain-type diabetes [184] [205].

Nevertheless, several researchers consider oxidative stress like the primary pathogenic mechanism, AD progenitor [77], considering this process as a possibility of the development of potential preventive treatment of AD [46] [206] [207]. There is a lot of scientific evidence that oxydative stress is increased in diabetes due to an increase of ROS production and a decrease of GSH [74] [194] [208]. A decreased synthesis and an altered metabolism of GSH levels have been found in hyperglycemia and diabetes. GSH concentration is diminished in erythrocytes and plasma in diabetic patients and in patients with MS, who have a high risk of suffering diabetes [85] 
[100]-[102].

Several clinical studies have demonstrated a strong correlation between circulating PAI-1 levels and cardiovascular events and mortality [209]. 80\% of patients with diabetes mellitus die from a thrombotic process, mainly from a cardiovascular process [16]. In this line, most of epidemic studies have demonstrated an increment of thromboembolic risk in diabetic patients [210]-[213]. Thromboembolic risk seems to be elevated in both clinical entities, type 1 and type 2 diabetes mellitus [211] [214]. In T2DM, hypercoagulability is attributed to a hypofibrinolysis with high PAI-1 levels [185] and a marked decreased plasmin activity. That is demonstrated as a prolongation of clot lysis time that expresses the systemic fibrinolytic activity [214]-[220].

Situations with proteolytic deficit are very frequent. Its maximum expression are systemic hypercoagulability and cerebral hipo- $\beta$-amiloidolysis, processes that go settling down during aging in a progressive way, and whose pathology is responsible for venous and arterial thromboembolic complications and accumulation of the peptide beta-amyloid cerebral, that characterize the more frequent pathology in aging (Table 1).

Some studies about the relationship between the proteasome activity and the age show that enzymatic activity of urokinase, plasmin, and thrombin were inversely correlated with age, suggesting certain relationship between the normal process of aging and AD pathology [221].

AD histopathology is characterized by brain accumulation of extracellular amyloid plaques [222]-[228] and intracellular neurofibrillary tangles, which are mainly composed of an abnormally hyperphosphorylated Tau protein [229]-[235].

T2DM is characterized by loss of beta cells and a deposition of islet amyloid derived from islet amyloid polypeptide. They are initially formed in an intra cellular level and they are released to extra cellular space by exocytosis [18] [236]-[239]. Amyloid deposition in brain and pancreas has some strong pathophysiological similarities. Neurodegeneration in pancreatic islet has been less studied than in AD but it may also occur [240]. Nevertheless, in pathological studies in brain and pancreas, amyloid islets are more frequent in patient with AD than in controls and they are more common in brain in patients with T2DM than in no diabetics [18]. In autopsy studies it is shown that above 96\% of patients with T2DM present islet amyloid [241] [242]. Likewise, other neurodegenerative processes, such as Huntington's disease, Friedrich's ataxia, Werner's disease and Myotonic dystrophy, are associated with the development of T2DM [243]-[245].

Table 1. Mechanism t-PA/plasminogen/plasmine and glutathione in aging pathology and in centennials. Experimental design.

\begin{tabular}{|c|c|c|c|c|c|c|c|}
\hline PROCESS & GSH & t-PA & PLASM & PAI-1 & $\alpha 2-\mathrm{AP}$ & Ant Def & PA \\
\hline TED & $\downarrow$ & $\downarrow$ & $\downarrow$ & $\uparrow$ & $\mathrm{N}$ & $\downarrow$ & $\downarrow$ \\
\hline Obesity & $\downarrow$ & $\downarrow$ & $\downarrow$ & $\uparrow$ & $\mathrm{N}$ & $\downarrow$ & $\downarrow$ \\
\hline Hyperinsulinemia & $\downarrow$ & $\downarrow$ & $\downarrow$ & $\uparrow$ & $\mathrm{N}$ & $\downarrow$ & $\downarrow$ \\
\hline Hyperglycemia & $\downarrow$ & $\downarrow$ & $\downarrow$ & $\uparrow$ & $\mathrm{N}$ & $\downarrow$ & $\downarrow$ \\
\hline Insulin resistance & $\downarrow$ & $\downarrow$ & $\downarrow$ & $\uparrow$ & $\mathrm{N}$ & $\downarrow$ & $\downarrow$ \\
\hline Type 2 Diabetes mellitus & $\downarrow$ & $\downarrow$ & $\downarrow$ & $\uparrow$ & $\mathrm{N}$ & $\downarrow$ & $\downarrow$ \\
\hline Alzheimer's disease. & $\downarrow$ & $\downarrow$ & $\downarrow$ & $\uparrow$ & $N-\uparrow$ & $\downarrow$ & $\stackrel{\downarrow}{\stackrel{\downarrow}{A} \boldsymbol{\beta}}$ \\
\hline Intracerebral BSO & $\downarrow$ & $\downarrow$ & $\downarrow$ & $\uparrow$ & $\mathrm{N}$ & $\downarrow$ & $\begin{array}{c}\downarrow \\
\mathbf{A} \boldsymbol{\beta}\end{array}$ \\
\hline Systemic BSO & $\downarrow$ & $\downarrow$ & $\downarrow$ & $\uparrow$ & $\mathrm{N}$ & $\downarrow$ & $\downarrow$ \\
\hline Intracerebral DM & $\downarrow$ & $\downarrow$ & $\downarrow$ & $\uparrow$ & $\mathrm{N}$ & $\downarrow$ & $\stackrel{\downarrow}{\mathbf{A} \beta}$ \\
\hline Systemic DM & $\downarrow$ & $\downarrow$ & $\downarrow$ & $\uparrow$ & $\mathrm{N}$ & $\downarrow$ & $\downarrow$ \\
\hline Centennials & $\uparrow$ & $\mathrm{N}$ & $\uparrow$ & $\mathrm{N}$ & $\mathrm{N}$ & $\uparrow$ & $\uparrow$ \\
\hline
\end{tabular}

TED: Thromboembolic disease. BSO: Buthionine sulfoximine. DM: Diethyl maleate. GSH: Glutathione. t-PA: Tissue plasminogen activator. PLASM: Plasmin. PAI-1: Plasminogen activator Inhibitor-1. $\alpha 2$-AP: Alfa-2 antiplasmin. Ant. Def: Antioxidant Defense. PA = Proteolytic activity. $\uparrow=$ increase. $\downarrow=$ Decrease. $\mathrm{N}=$ Normal. $\mathrm{A} \beta$ : amyloid beta peptides. 
The mechanism of the incremented $\mathrm{A} \beta$ accumulation in common $\mathrm{AD}$ has not been completely clarified. It has been well documented the importance of oxidative stress in aging. A progressive increase of oxidative stress in the aging development plays an important role in $\mathrm{AD}$ pathology, mainly in the neuronal death and $\mathrm{A} \beta$ accumulation in the brain [13] [246]-[248]. In this line, it is of interest to point out as oxidative stress, a metabolic characteristic of the pathological processes that accompany the development of the aging, involves an increased PAI-1 expression [19] [249], which is considered as a pharmacological target by different authors, mainly in AD. Indeed, the inhibition of PAI-1 activity with specific inhibitors reduces brain $\mathrm{A} \beta$ burden and reverses cognitive deficit in the AD model in mice [250] [251]. It is of great interest to point out the results found by Liu and collaborators [251] with administration of the fenolic compound Tert-Butyl Hydroquinone (TBHQ) in the diet to mice. This is an effective anti-oxidative used in food and cosmetic products as a preservative. These authors took account the evidence of the increase of PAI-1 expression in the development of the amyloidosis in AD. Two groups $\mathrm{A} \beta \mathrm{PP} / \mathrm{PS} 1$ double transgenic mice were fed with either a control or $1 \%$ TBHQ-containing diet for 6 weeks. This study showed that TBHQ administration significantly reduced the brain A $\beta$ load in A $\beta$ PP/PS1 mice getting an inhibition of PAI-1 expression and an increase in the activities of tissue and urokinase types plasminogen activator, plasmin and an increase of GSH level in brain of $\mathrm{A} \beta \mathrm{PP} / \mathrm{ps}$ mice. These results lead us to consider that GSH could play an essential role in regulation of the different components of the fibrinolytic system in the brain [50].

The experimental rehearse through the decrease of cerebral GSH levels with BSO allows us to value its effect in the cerebral anti-oxidative mechanisms. A widely used approach to study the physiological function of glutathione has been the depletion of its intracellular levels with BSO [57] [58]. The induction of pharmacological depletion of GSH causes neurodegenerative alterations [252]. Furthermore, GSH depletion is found in the neurodegenerative diseases associated with oxidative stress [98]. GSH depletion can affect the severity of the cerebral attack induced by ischemia [253]. These results show that the intensity of the cerebral attack is related to the reduction of GSH levels in the injured area of the cerebral cortex.

\section{PAI-1 Inhibition}

Some clinical studies about antithrombotic treatments have demonstrated that the inhibition of the PAI-1 produces an endogenous increase of the fibrinolytic activity [254]-[257]. In our experience we have observed that the treatment with sulodexide, an inhibitor of PAI-1 activity, in the prevention of secondary thrombosis in AD in long term produces positive results due to its pharmacological effect [258] [259]. These clinical observations suggest the hypothesis that aging develops a sequence of processes such as obesity, MS, as well as clinical entities such as T2DM and AD, with a common denominator, the increase of the PAI-1. PAI-1 is the origin of the decrease of systemic fibrinolytic and cerebral proteolytic activities and it causes the thromboembolic complications so frequent in these processes that are the main cause of death in these patients. The possible causal agent is the decrease of GSH synthesis, and, in hypothesis, its pathogenic relationship with T2DM and AD.

At clinical and experimental level, this increase of PAI-1 with decreased proteolytic activity is normalized with the restoration of cellular GSH synthesis [50]. It suggests possible benefits with treatments with PAI-1 inhibitors [260]-[264], such as glycosaminoglycans [265] [266], sulodexide [258] [267], GSH administration at systemic level to normalize the cell concentration [268] [269] or with their precursors to activate the GSH synthesis at cerebral level [270] [271]. It is possible that cerebral mechanisms of GSH and fibrinolysis/ ß-amyloidosis, can be fundamental pillars in the prevention of aging pathology (TED, MS, T2DM and AD). Their normal function during the aging brings the subjects to become centenarians. In fact, in centenarians, the glutathione reductase activity (leading to GSH synthesis) is normal or high [272] [273] and t-PA/plasminogen/plasmin and PAI-1 mechanisms are normal, but there is an increase of secondary fibrinolytic activity paradoxically [24] [25] [274].

\section{Conclusions}

This revision shows like a concatenation of processes sustained by the intractable problem of aging such as TED, MS, T2DM, and AD; they are closely united for two pathophysiological situations, a) decrease of GSH and b) depletion of proteolytic systems: systemic fibrinolytic system and $\beta$-amyloidolytic system in the brain, and all of them present increased PAI-1 levels.

Oxidative stress is a present process in the development of aging, which accompanies its pathology and it is 
responsible for the deterioration of the anti-oxidative mechanism. It is demonstrated by the GSH descent, as much as systemic level as in the brain. At the same time there is a PAI-1 increase, central factor that accompanies the aging and their pathologies, creating a systemic hypofibrinolysis/hypobeta-amyloidolysis in brain, responsible for systemic thromboembolic complications, stroke, as well as, for the beta-amyloid deposits in T2DM and $\mathrm{AD}$.

PAI-1 inhibition involves an endogenous increase of the fibrinolytic activity. PAI-1 inhibitors treatments would produce positive results due to its pharmacological effect. It is suggested that aging develops a sequence of processes such as obesity, MS, as well as, clinical entities such as T2DM and AD, with a common denominator - the increase of the PAI-1. PAI-1 is the origin of the decrease of systemic fibrinolytic activity and cerebral proteolytic activity and it causes the thromboembolic complications. The possible causal agent is the decrease of the synthesis of the GSH, and, in hypothesis, its pathogenic relationship with T2DM and AD.

At clinical and experimental level, this increase of the PAI-1 with decreased proteolytic activity is normalized with the restoration of the cellular GSH synthesis. It suggests possible benefits with PAI-1 inhibitors treatments, such as glycosaminoglycan, sulodexide, GSH administration or GSH precursors. It is possible that the cerebral mechanisms of GSH and fibrinolysis/ß-amyloidosis can be fundamental pillars in the prevention of aging pathology (TED, MS, T2DM and AD). In fact, in centenarians, glutathione reductase activity (leading to GSH synthesis) is normal or high and t-PA/plasminogen/plasmin and PAI-1 mechanisms are normal but paradoxically there is an increase of secondary fibrinolytic activity.

As final reflection, some clinical evidence suggests the necessity to propose prospective studies in the different pathologies that accompany aging using PAI-1 inhibitors as pharmacological procedures, to corroborate the clinical benefits in the different processes in aging in the short term.

\section{References}

[1] Werner, C.A. (2011) The Older Population: 2010. 2010 Census BrPARA ENVIARiefs, US Census Bureau, Washington DC.

[2] Hoyert, D.L. (2012) 75 Years of Mortality in the United States, 1935-2010. NCHS Data Brief, No. 88. National Center for Health Statistics, Hyattsville.

[3] LaCroix, A.Z. (2013) Epidemiologic Reviews on Aging. American Journal of Epidemiology, 177, 377-379. http://dx.doi.org/10.1093/aje/kwt011

[4] Diczfalusy, E. (2001) The Demographic Revolution and Our Common Future. Maturitas, 38, 5-14. http://dx.doi.org/10.1016/S0378-5122(00)00187-0

[5] Candore, G., Balistreri, C.R., Listi, F., Grimaldi, M.P., Vasto, S., Colonna-Romano, G., et al. (2006) Inmunogenetics, Gender, and Longevity. Annals of the New York Academy of Sciences, 1089, 516-537. http://dx.doi.org/10.1196/annals.1386.051

[6] Harman, D. (1956) Aging: A Theory Based on Free Radical and Radiation Chemistry. Journals of Gerontology, 11, 298-300. http://dx.doi.org/10.1093/geronj/11.3.298

[7] Stadtman, E.R. (1992) Protein Oxidation and Aging. Science, 257, 1220-1224. http://dx.doi.org/10.1126/science.1355616

[8] Dringen, R. (2000) Metabolism and Functions of Glutathione in Brain. Progress in Neurobiology, 62, 649-671. http://dx.doi.org/10.1016/S0301-0082(99)00060-X

[9] Harman, D. (2003) The Free Radical Theory of Aging. Antioxidants \& Redox Signaling, 5, 557-561. http://dx.doi.org/10.1089/152308603770310202

[10] Guidi, I., Galimberti, D., Lonati, S., Novembrino, C., Bamonti, F., Tiriticco, M., et al. (2006) Oxidative Imbalance in Patients with Mild Cognitive Impairment and Alzheimer's Disease. Neurobiology of Aging, 27, 262-269. http://dx.doi.org/10.1016/j.neurobiolaging.2005.01.001

[11] Yamamoto, K., Takeshita, K., Shimokawa, T., Yi, H., Isobe, K., Loskutoff, D.J., et al. (2002) Plasminogen Activator Inhibitor-1 Is a Major Stress-Regulated Gene: Implications for Stress-Induced Thrombosis in Aged Individuals. Proceedings of the National Academy of Sciences of the United States of America, 99, 890-895. http://dx.doi.org/10.1073/pnas.022608799

[12] Yamamoto, K., Takeshita, K., Kojima, T., Takamatsu, J. and Saito, H. (2005) Aging and Plasminogen Activator Inhibitor-1 (PAI-1) Regulation: Implication in the Pathogenesis of Thrombotic Disorders in the Elderly. Cardiovascular Research, 66, 276-285. http://dx.doi.org/10.1016/j.cardiores.2004.11.013

[13] Lasierra-Cirujeda, J., Coronel, P., Aza, M.J. and Gimeno, M. (2013) Beta-Amyloidolysis and Glutathione in Alzhei- 
mer's Disease. Journal of Blood Medicine, 4, 31-38. http://dx.doi.org/10.2147/JBM.S35496

[14] Hashimoto, Y., Kobayashi, A., Yamazaki, N., Sugawara, Y., Takada, Y. and Takada, A. (1987) Relationship between Age and Plasma T-PA, PA-Inhibitor, and PA Activity. Thrombosis Research, 46, 625-633. http://dx.doi.org/10.1016/0049-3848(87)90264-7

[15] Aza Pascual-Salcedo, M.M. (1992) Evaluation of Fibrinolytic System in Diabetic Patients. Doctoral Thesis, University of Navarra, Pamplona.

[16] Carr, M.E. (2001) Diabetes Mellitus: A Hypercoagulable State. Journal of Diabetes and Its Complications, 15, 44-54. http://dx.doi.org/10.1016/S1056-8727(00)00132-X

[17] Aso, Y., Matsumoto, S., Fujiwara, K., Tayama, K., Inukai, T. and Takemura, Y. (2002) Impaired Fibrinolytic Compensation for Hypercoagulability in Obese Patients with Type 2 Diabetes: Association with Increased Plasminogen Activator Inhibitor-1. Metabolism, 51, 471-476. http://dx.doi.org/10.1053/meta.2002.31334

[18] Janson, J., Laedtke, T., Parisi, J.E., O’Brien, P., Petersen, R.C. and Butler, P.C. (2004) Increased Risk of Type 2 Diabetes in Alzheimer Disease. Diabetes, 53, 474-481. http://dx.doi.org/10.2337/diabetes.53.2.474

[19] Dimova, E.Y., Samoylenko, A. and Kietzmann, T. (2004) Oxidative Stress and Hypoxia: Implications for Plasminogen Activator Inhibitor-1 Expression. Antioxidants \& Redox Signaling, 6, 777-791. http://dx.doi.org/10.1089/1523086041361596

[20] Dunn, E.J. and Grant, P.J. (2005) Type 2 Diabetes: An Atherothrombotic Syndrome. Current Molecular Medicine, 5, 323-332. http://dx.doi.org/10.2174/1566524053766059

[21] Naderali, E.K., Ratcliffe, S.H. and Dale, M.C. (2009) Obesity and Alzheimer's Disease: A Link between Body Weight and Cognitive Function in Old Aged. American Journal of Alzheimer's Disease \& Other Dementias, 24, 445-449. http://dx.doi.org/10.1177/1533317509348208

[22] Meigs, J.B., Mittleman, M.A., Nathan, D.M., Tofler, G.H., Singer, D.E., Murphy-Sheehy, P.M., et al. (2000) Hyperinsulinemia, Hyperglycemia, and Impaired Hemostasis: The Framingham Offspring Study. The Journal of the American Medical Association, 283, 221-228. http://dx.doi.org/10.1001/jama.283.2.221

[23] Erden-Inal, M., Sunal, E. and Kanbak, G. (2002) Age-Related Changes in the Glutathione Redox System. Cell Biochemistry and Function, 20, 61-66. http://dx.doi.org/10.1002/cbf.937

[24] Mari, D., Coppola, R. and Provenzano, R. (2008) Hemostasis Factors and Aging. Experimental Gerontology, 43, 66-73. http://dx.doi.org/10.1016/j.exger.2007.06.014

[25] Mari, D., Ogliari, G., Castaldi, D., Vitale, G., Bollini, E.M. and Lio, D. (2008) Hemostasis and Ageing. Immunity \& Ageing, 5, 12. http://dx.doi.org/10.1186/1742-4933-5-12

[26] Tracy, R.P. and Bovill, E.G. (1992) Thrombosis and Cardiovascular Risk in the Elderly. Archives of Pathology \& Laboratory Medicine, 116, 1307-1312.

[27] Sagripanti, A. and Carpi, A. (1998) Natural Anticoagulants, Aging, and Thromboembolism. Experimental Gerontology, 33, 891-896. http://dx.doi.org/10.1016/S0531-5565(98)00047-3

[28] Wilkerson, W.R. and Sane, D.C. (2002) Aging and Thrombosis. Seminars in Thrombosis and Hemostasis, 28, 555-568. http://dx.doi.org/10.1055/s-2002-36700

[29] Rosendaal, F.R., Van Hylckama Vlieg, A. and Doggen, C.J. (2007) Venous Thrombosis in the Ederly. Journal of Thrombosis and Haemostasis, 5, 310-317. http://dx.doi.org/10.1111/j.1538-7836.2007.02489.x

[30] Engbers, M.J., van Hylckama Vlieg, A. and Rosendaal, F.R. (2010) Venous Thrombosis in the Ederly: Incidence, Risk Factors and Risk Groups. Journal of Thrombosis and Haemostasis, 8, 2105-2112. http://dx.doi.org/10.1111/j.1538-7836.2010.03986.x

[31] Balleisen, L., Bailey, J., Epping, P.H., Schulte, H. and van de Loo, J. (1985) Epidemiological Study on Factor VII, factor VIII and Fibrinogen in an Industrial Population: I. Baseline Data on the Relation to Age, Gender, Body-Weight, Smoking, Alcohol, Pill-Using, and Menopause. Thrombosis and Haemostasis, 54, 475-479.

[32] Lakatta, E.G., Mitchell, J.H., Pomerance, A. and Rowe, G.G. (1987) Human Aging: Changes in Structure and Function. Journal of the American College of Cardiology, 10, 42A-47A. http://dx.doi.org/10.1016/S0735-1097(87)80447-3

[33] Abbate, R., Prisco, D., Rostagno, C., Boddi, M. and Gensini, G.F. (1993) Age-Related Changes in the Hemostatic System. International Journal of Clinical and Laboratory Research, 23, 1-3. http://dx.doi.org/10.1007/BF02592271

[34] Yamamoto, Y., Ishizu, A., Ikeda, H., Otsuka, N. and Yoshiki, T. (2004) Dexamethasone Increased Plasminogen Activator Inhibitor-1 Expression on Human Umbilical Vein Endothelial Cells: An Additive Effect to Tumor Necrosis Factor- $\alpha$. Pathobiology, 71, 295-301. http://dx.doi.org/10.1159/000081724

[35] Loskutoff, D.J., Sawdey, M. and Mimuro, J. (1989) Type 1 Plasminogen Activator Inhibitor. Progress in Hemostasis and Thrombosis, 9, 87-115. 
[36] Tofler, G.H., Massaro, J., Levy, D., Mittleman, M., Sutherland, P., Lipinska, I., et al. (2005) Relation of the Prothrombotic State to Increasing Age (from the Framingham Offspring Study). The American Journal of Cardiology, 96, 1280-1283. http://dx.doi.org/10.1016/j.amjcard.2005.06.072

[37] Metzer, M.E., Lisman, T., de Groot, P.G., Meijers, J.C., le Cessie, S., Doggen, C.J., et al. (2010) Venous Thrombosis Risk Associated with Plasma Hypofibrinolysis Is Explained by Elevated Plasma Level of TAFI and PAI-1. Blood, 116, 113-121. http://dx.doi.org/10.1182/blood-2010-02-267740

[38] Juhan-Vague, I., Alessi, M.C. and Morange, P.E. (2000) Hypofibrinolysis and Increased PAI-1 Are Linked to Atherothrombosis via Insulin Resistance and Obesity. Annals of Medicine, 32, 78-84.

[39] McGrath, L.T., McGleenon, B.M., Brennan, S., McColl, D., McILroy, S. and Passmore, A.P. (2001) Increased Oxidative Stress in Alzheimer's Disease as Assessed with 4-Hydroxynonenal but not Malondialdehyde. QJM: An International Journal of Medicine, 94, 485-490. http://dx.doi.org/10.1093/ajmed/94.9.485

[40] Butterfield, D.A. (2002) Amyloid Beta-Peptide (1-42)-Induced Oxidative Stress and Neurotoxicity: Implications for Neurodegeneration in Alzheimer’s Disease Brain. A Review. Free Radical Research, 36, 1307-1313. http://dx.doi.org/10.1080/1071576021000049890

[41] Dringen, R. and Hirrlinger, J. (2003) Glutathione Pathways in the Brain. Biological Chemistry, 384, 505-516. http://dx.doi.org/10.1515/BC.2003.059

[42] Urakawa, H., Katsuki, A., Sumida, Y., Gabazza, E.C., Murashima, S., Morioka, K., et al. (2003) Oxidative Stress Is Associated with Adiposity and Insulin Resistance in Men. The Journal of Clinical Endocrinology \& Metabolism, 88, 4673-4676. http://dx.doi.org/10.1210/jc.2003-030202

[43] Ceriello, A. and Motz, E. (2004) Is Oxidative Stress the Pathogenic Mechanism Underlying Insulin Resistance, Diabetes, and Cardiovascular Disease? The Common Soil Hypothesis Revisited. Arteriosclerosis, Thrombosis, and Vascular Biology, 24, 816-823. http://dx.doi.org/10.1161/01.ATV.0000122852.22604.78

[44] Stegenga, M.E., van der Crabben, S.N., Levi, M., de Vos, A.F., Tanck, M.W., Sauerwein, H.P., et al. (2006) Hyperglycemia Stimulates Coagulation, Whereas Hyperinsulinemia Impairs Fibrinolysis in Health Human. Diabetes, 55, 18071812. http://dx.doi.org/10.2337/db05-1543

[45] Piazza, G., Goldhaber, S.Z., Kroll, A., Goldberg, R.J., Emery, C. and Spencer, F.A. (2012) Venous Thromboembolism in Patients with Diabetes Mellitus. The American Journal of Medicine, 125, 709-716. http://dx.doi.org/10.1016/j.amjmed.2011.12.004

[46] Li, J., O, W., Li, W., Jiang, Z.-G. and Ghanbari, H.A. (2013) Oxidative Stress and Neurodegenerative Disorders. International Journal of Molecular Sciences, 14, 24438-24475. http://dx.doi.org/10.3390/ijms141224438

[47] Aoyama, K. and Nakaki, T. (2013) Impaired Glutathione Synthesis in Neurodegeneration. International Journal of Molecular Sciences, 14, 21021-21044. http://dx.doi.org/10.3390/ijms141021021

[48] Swiatkowska, M., Szemraj, J., Al-Nedawi, K.N. and Pawlowska, Z. (2002) Reactive Oxigen Species Upregulate Expression of PAI-1 in Endothelial Cells. Cellular \& Molecular Biology Letters, 7, 1065-1071.

[49] Sakkinen, P.A., Wahl, P., Cushman, M., Lewis, M.R. and Tracy, R.P. (2000) Clustering of Procoagulation, Inflammation, and Fibrinolysis Variables with Metabolic Factors in Insulin Resistance Syndrome. American Journal of Epidemiology, 152, 897-907. http://dx.doi.org/10.1093/aje/152.10.897

[50] Lasierra, J., Aza, M.J., Collado, P.S., González, J. and Esteller, A. (1989) Inhibition of Fibrinolysis by Cellular Glutathione Depletion in the Rabbit. Thrombosis Research, 53, 347-355. http://dx.doi.org/10.1016/0049-3848(89)90313-7

[51] Griffith, O.W. (1999) Biologic and Pharmacologic Regulation of Mammalian Glutathione Synthesis. Free Radical Biology and Medicine, 27, 922-935. http://dx.doi.org/10.1016/S0891-5849(99)00176-8

[52] Jones, D.P. (2002) Redox Potential of GSH/GSSG Couple: Assay and Biological Significance. Methods in Enzymology, 348, 93-112. http://dx.doi.org/10.1016/S0076-6879(02)48630-2

[53] Meister, A. (1974) Glutathione, Metabolism and Function via the Gamma-Glutamyl Cycle. Life Sciences, 15, $177-190$. http://dx.doi.org/10.1016/0024-3205(74)90206-9

[54] Huang, C.S., Chang, L.S., Anderson, M.E. and Meister, A. (1993) Catalytic and Regulatory Properties of the Heavy Subunit of Rat Kidney Gamma-Glutamylcysteine Synthetase. The Journal of Biological Chemistry, 268, 19675-19680.

[55] Forman, H.J., Zhang, H. and Rinna, A. (2009) Glutathione: Overview of Its Prospective Roles, Measurement, and Biosynthesis. Molecular Aspects of Medicine, 30, 1-12. http://dx.doi.org/10.1016/j.mam.2008.08.006

[56] Griffith, O.W. and Meister, A. (1979) Potent and Specific Inhibition of Glutathione Synthesis by Buthionine Sulfoximine (S-n-Butyl Homocysteine Sulfoximine). The Journal of Biological Chemistry, 254, 7558-7560.

[57] Meister, A. and Anderson, M.E. (1983) Glutathione. Annual Review of Biochemistry, 52, 711-760. http://dx.doi.org/10.1146/annurev.bi.52.070183.003431

[58] Aza, M.J., Gonzalez, J. and Esteller, A. (1986) Effect of Diethyl Maleate Pretreatment on Biliary Excretion and Cho- 
leretic Action of Sulfobromophthalein in Rats. Archives Internationales de Pharmacodynamie et de Thérapie, 281, 321- 330.

[59] Ames, B.N., Shigenaga, M.K. and Hagen, T.M. (1993) Oxidants, Antioxidants, and the Degenerative Diseases of Aging. Proceedings of the National Academy of Sciences of the United States of America, 90, 7915-7922. http://dx.doi.org/10.1073/pnas.90.17.7915

[60] Joseph, J.A. and Cutler, R.C. (1994) The Role of Oxidative Stress in Signal Transduction Changes and Cell Loss in Senescence. Annals of the New York Academy of Sciences, 738, 37-43. http://dx.doi.org/10.1111/j.1749-6632.1994.tb21787.x

[61] Beckman, K.B. and Ames, B.N. (1998) The Free Radical Theory of Aging Matures. Physiological Reviews, 78, 547581.

[62] Halliwell, B. and Gutteridge, J.M.C. (2015) Free Radicals in Biology and Medicine. 5th Edition, Oxford University Press, New York. http://dx.doi.org/10.1093/acprof:oso/9780198717478.001.0001

[63] Gray, D.A., Tsirigotis, M. and Woulfe, J. (2003) Ubiquitin, Proteasomes, and the Aging Brain. Science of Aging Knowledge Environment, 34, Re6. http://dx.doi.org/10.1126/sageke.2003.34.re6

[64] Wu, G., Fang, Y.Z., Yang, S., Lupton, J.R. and Turner, N.D. (2004) Glutathione Metabolism and Its Implications for Health. Journal of Nutrition, 134, 489-492.

[65] Hall, A.G. (1999) Review: The Role of Glutathione in the Regulation of Apoptosis. European Journal of Clinical Investigation, 29, 238-245. http://dx.doi.org/10.1046/j.1365-2362.1999.00447.X

[66] Julius, M., Lang, C.A., Gleiberman, L., Harburg, E., Difranceisco, W. and Schork, A. (1994) Glutathione and Morbidity in a Community-Based Sample of Elderly. Journal of Clinical Epidemiology, 47, 1021-1026. http://dx.doi.org/10.1016/0895-4356(94)90117-1

[67] Liu, R. and Choi, J. (2000) Age-Associated Decline in Gamma-Glutamylcysteine Synthetase Gene Expression in Rats. Free Radical Biology and Medicine, 28, 566-574. http://dx.doi.org/10.1016/S0891-5849(99)00269-5

[68] Zhu, Y., Carvey, P.M. and Ling, Z. (2006) Age-Related Changes in Glutathione and Glutathione-Related Enzymes in Rat Brain. Brain Research, 1090, 35-44. http://dx.doi.org/10.1016/j.brainres.2006.03.063

[69] Sohal, R.S. and Weindruch, R. (1996) Oxidative Stress, Caloric Restriction, and Aging. Science, 273, 59-63. http://dx.doi.org/10.1126/science.273.5271.59

[70] Ravindranath, V., Shivakumar, B.R. and Anandatheerthavarada, H.K. (1989) Low Glutathione Levels in Brain Regions of Aged Rats. Neuroscience Letters, 101, 187-190. http://dx.doi.org/10.1016/0304-3940(89)90528-4

[71] Lang, C.A., Naryshkin, S., Schneider, D.L., Mills, B.J. and Lindeman, R.D. (1992) Low Blood Glutathione Levels in Healthy Aging Adults. The Journal of Laboratory and Clinical Medicine, 120, 720-725.

[72] Fletcher, R.H. and Fletcher, S.W. (1994) Glutathione and Ageing: Ideas and Evidence. The Lancet, 344, $1379-1380$. http://dx.doi.org/10.1016/S0140-6736(94)90562-2

[73] Nuttall, S.L., Martin, U., Sinclair, A.J. and Kendall, M.J. (1998) Glutathione: In Sickness and in Health. The Lancet, 35, 645-646. http://dx.doi.org/10.1016/S0140-6736(05)78428-2

[74] Samiec, P.S., Drews-Botsch, C., Flagg, E.W., Kurtz, J.C., Stemberg Jr., P., Reed, R.L., et al. (1998) Glutathione in Human Plasma: Decline in Association with Aging, Age-Related Macular Degeneration, and Diabetes. Free Radical Biology and Medicine, 24, 699-704. http://dx.doi.org/10.1016/S0891-5849(97)00286-4

[75] Cudkowicz, M.E., Sexton, P.M., Ellis, T., Hayden, D.L., Gwilt, P.R., Whalen, J., et al. (1999) The Pharmacokinetics and Pharmaco-Dynamics of Procysteine in Amyotrophic Lateral Sclerosis. Neurology, 52, 1492-1494. http://dx.doi.org/10.1212/WNL.52.7.1492

[76] Dringen, R., Gutterer, J.M. and Hirrlinger, J. (2000) Glutathione Metabolism in Brain: Metabolic Interaction between Astrocytes and Neurons in the Defense against Reactive Oxygen Species. The FEBS Journal, 267, 4912-4916. http://dx.doi.org/10.1046/j.1432-1327.2000.01597.x

[77] Liu, H., Wang, H., Shenvi, S., Hagen, T.M. and Liu, R.M. (2004) Glutathione Metabolism during Aging and in Alzheimer Disease. Annals of the New York Academy of Sciences, 1019, 346-349. http://dx.doi.org/10.1196/annals.1297.059

[78] Toroser, D. and Sohal, R.S. (2007) Age-Associated Perturbations in Glutathione Synthesis in Mouse Liver. Biochemical Journal, 405, 583-589. http://dx.doi.org/10.1042/BJ20061868

[79] Friguet, B., Bulteau, A.L., Chondrogianni, N., Conconi, M. and Petropoulos, I. (2000) Protein Degradation by the Proteasome and Its Implications in Aging. Annals of the New York Academy of Sciences, 908, 143-154. http://dx.doi.org/10.1111/j.1749-6632.2000.tb06643.x

[80] Keller, J.N., Gee, J. and Ding, Q. (2002) The Proteasome in Brain Aging. Ageing Research Reviews, 1, 279-293. http://dx.doi.org/10.1016/S1568-1637(01)00006-X 
[81] Zeng, B.Y., Medhurst, A.D., Jackson, M., Rose, S. and Jenner, P. (2005) Proteasomal Activity in Brain Differs between Species and Brain Regions and Changes with Age. Mechanisms of Ageing and Development, 126, 760-766. http://dx.doi.org/10.1016/j.mad.2005.01.008

[82] Hampton, T. (2005) Study Reveals Mitochondrial Role in Aging. JAMA: The Journal of the American Medical Association, 294, 672. http://dx.doi.org/10.1001/jama.294.6.672

[83] Lovell, M.A., Ehmann, W.D., Butle, S.M. and Markesbery, W.R. (1995) Elevated Thiobarbituric Acid-Reactive Substances and Antioxidant Enzyme Activity in the Brain in Alzheimer's Disease. Neurology, 45, 1594-1601. http://dx.doi.org/10.1212/WNL.45.8.1594

[84] Townsend, D.M., Tew, K.D. and Tapiero, H. (2003) The Importance of Glutathione in Human Disease. Biomedicine \& Pharmacotherapy, 57, 145-155. http://dx.doi.org/10.1016/S0753-3322(03)00043-X

[85] Ballatori, N., Krance, S.M., Notenboom, S., Shi, S., Tieu, K. and Hammond, C.L. (2009) Glutathione Dysregulation and the Etiology and Progression of Human Diseases. Biological Chemistry, 390, 191-214. http://dx.doi.org/10.1515/BC.2009.033

[86] Shivakumar, B.B. and Ravindranath, V. (1992) Selective Modulation of Glutathione in Mouse Brain Regions and Its Effect on Acrylamide-Induced Neurotoxicity. Biochemical Pharmacology, 43, 263-269. http://dx.doi.org/10.1016/0006-2952(92)90287-S

[87] Clarke, D.D. and Sokoloff, L. (1999) Circulation and Energy Metabolism of the Brain. In: Siegel, G.J., Agranof, B.W., Albers, R.W., Fisher, S.K. and Uhler, M.D., Eds., Basic Neurochemistry: Molecular Cellular and Medical Aspects, 6th Edition, Lippincott-Raven, Philadelphia, 637-669.

[88] Cooper, A.J.L. (1997) Glutathione in the Brain: Disorders of Glutathione Metabolism. In: Rosenberg, R.N., Prusiner, S.B., Dimauro, S., Barchi, R.L. and Kunk, L.M., Eds., The Molecular and Genetic Basis of Neurological Disease, Butterworth-Heinemann, Boston, 1195-1230.

[89] Langeveld, C.H., Schepens, E., Jongenelen, C.A., Stoof, J.C., Hjelle, O.P., Ottersen, O.P., et al. (1996) Presence of Glutathione Immunoreactivity in Cultured Neurones and Astrocytes. Neuroreport, 7, 1833-1836. http://dx.doi.org/10.1097/00001756-199607290-00029

[90] Sagara, J.I., Miura, K. and Bannai, S. (1993) Maintenance of Neuronal Glutathione by Glial Cells. Journal of Neurochemistry, 61, 1672-1677. http://dx.doi.org/10.1111/j.1471-4159.1993.tb09802.x

[91] Wang, X.F. and Cynader, M.S. (2000) Astrocytes Provide Cysteine to Neurons by Releasing Glutathione. Journal of Neurochemistry, 74, 1434-1442. http://dx.doi.org/10.1046/j.1471-4159.2000.0741434.x

[92] Aoyama, K., Watabe, M. and Nakaki, T. (2008) Regulation of Neuronal Glutathione Synthesis. Journal of Pharmaceutical Sciences, 108, 227-238. http://dx.doi.org/10.1254/jphs.08R01CR

[93] Hirrlinger, J., Schulz, J.B. and Dringen, R. (2002) Glutathione Release from Cultured Brain Cells: Multidrug Resistance Protein 1 Mediates the Release of GSH from Rat Astroglial Cells. Journal of Neuroscience Research, 69, 318326. http://dx.doi.org/10.1002/jnr.10308

[94] Smith, C.D., Carney, J.M., Starke-Reed, P.E., Oliver, C.N., Stadtman, E.R., Floyd, R.A., et al. (1991) Excess Brain Protein Oxidation and Enzyme Dysfunction in Normal Aging and in Alzheimer's Disease. Proceedings of the National Academy of Sciences of the United States of America, 88, 10540-10543. http://dx.doi.org/10.1073/pnas.88.23.10540

[95] Coyle, J.T. and Puttfarcken, P. (1993) Oxidative Stress, Glutamate and Neurodegenerative Disorders. Science, 262, 689-695. http://dx.doi.org/10.1126/science.7901908

[96] Sian, J., Dexter, D.T., Lees, A.J., Daniel, S., Agid, Y., Javoy-Agid, F., et al. (1994) Alterations in Glutathione Level in Parkinson's Disease and Other Neurodegenerative Disorders Affecting Basal Ganglia. Annals of Neurology, 36, 348355. http://dx.doi.org/10.1002/ana.410360305

[97] Good, P.F., Werner, P., Hsu, A., Olanow, C.W. and Perl, D.P. (1996) Evidence of Neuronal Oxidative Damage in Alzheimer's Disease. American Journal of Pathology, 149, 21-28.

[98] Schulz, J.B., Lindenau, J., Seyfrien, J. and Dichgans, J. (2000) Glutathione, Oxidative Stress and Neurodegeneration. The FEBS Journal, 267, 4904-4911. http://dx.doi.org/10.1046/j.1432-1327.2000.01595.x

[99] Lee, M., Cho, T., Jantaratnotai, N., Wang, Y.T., McGeer, E. and McGeer, P.L. (2010) Depletion of GSH in Glial Cells Induces Neurotoxicity: Relevance to Aging and Degenerative Neurological Diseases. The FASEB Journal, 24, 25332545. http://dx.doi.org/10.1096/fj.09-149997

[100] Yoshida, K., Hirokawa, J., Tagami, S., Kawakami, Y., Urata, Y. and Kondo, T. (1995) Weakened Cellular Scavenging Activity against Oxidative Stress in Diabetes Mellitus: Regulation of Glutathione Synthesis and Efflux. Diabetologia, 38, 201-210. http://dx.doi.org/10.1007/BF00400095

[101] Sharma, A., Kharb, S., Chugh, S.N., Kakkar, R. and Singh, G.P. (2000) Evaluation of Oxidative Stress before and after Control of Glycemia and after Vitamin E Supplementation in Diabetic Patients. Metabolism, 49, 160-162. 
http://dx.doi.org/10.1016/S0026-0495(00)91117-X

[102] Giral, P., Jacob, N., Dourmap, C., Hansel, B., Carrié, A., Bruckert, E., et al. (2008) Elevated Gamma-Glutamyltransferase Activity and Perturbed Thiol Profile Are Associated with Features of Metabolic Syndrome. Arteriosclerosis, Thrombosis, and Vascular Biology, 28, 587-593. http://dx.doi.org/10.1161/ATVBAHA.107.157891

[103] Isomaa, B., Almgren, P., Tuomi, T., Forsén, B., Lahti, K., Nissén, M., et al. (2001) Cardiovascular Morbidity and Mortality Associated with the Metabolic Syndrome. Diabetes Care, 24, 683-689. http://dx.doi.org/10.2337/diacare.24.4.683

[104] Yamamoto, K. (2007) [Thrombotic Tendency and Laboratory Medicine in Metabolic Syndrome]. Rinsho Byori. The Japanese Journal of Clinical Pathology, 55, 952-961. (In Japanese)

[105] Lakka, H.M., Laaksonen, D.E., Lakka, T.A., Niskanen, L.K., Kumpusalo, E., Tuomilehto, J., et al. (2002) The Metabolic Syndrome and Total and Cardiovascular Disease Mortality in Middle-Aged Men. JAMA: The Journal of the American Medical Association, 288, 2709-2716. http://dx.doi.org/10.1001/jama.288.21.2709

[106] Viinamäki, H., Heiskanen, T., Lehto, S.M., Niskanen, L., Koivumaa-Honkanen, H., Tolmunen, T., et al. (2009) Association of Depressive Symptoms and Metabolic Syndrome in Men. Acta Psychiatrica Scandinavica, 120, 23-29. http://dx.doi.org/10.1111/j.1600-0447.2008.01333.x

[107] Huotari, A., Lehto, S.M., Niskanen, L., Herzig, K.H., Hiintikka, J., koivumaa-Honkanen, H., et al. (2010) Increased Serum PAI-1 Levels in Subjects with Metabolic Syndrome and Long Term Adverse Mental Symptoms: A PopulationBased Study. Cardiovascular Psychiatry and Neurology, 2010, Article ID: 501349. http://dx.doi.org/10.1155/2010/501349

[108] Alberti, K.G., Zimmet, P. and Shaw, J., for the IDF Epidemiology Task Force Consensus Group (2005) The Metabolic Syndrome-A New Worldwide Definition. The Lancet, 366, 1059-1062. http://dx.doi.org/10.1016/S0140-6736(05)67402-8

[109] Alberti, K.G., Eckel, R.H., Grundy, S.M., Zimmet, P.Z., Cleeman, J.I., Donato, K.A., et al. (2009) Harmonizing the Metabolic Syndrome: A Joint Interim Statement of the International Diabetes Federation Task Force on Epidemiology and Prevention; National Heart, Lung, and Blood Institute; American Heart Association; World Heart Federation; International Atherosclerosis Society; and International Association for the Study of Obesity. Circulation, 120, 16401645. http://dx.doi.org/10.1161/CIRCULATIONAHA.109.192644

[110] Larsson, B., Svärdsudd, K., Welin, L., Wilhelmsen, L., Björntorp, P. and Tibblin, G. (1984) Abdominal Adipose Tissue Distribution, Obesity, and Risk of Cardiovascular Disease and Death: 13 Year Follow-Up of Participants in the Study of Men Born in 1913. British Medical Journal (Clinical Research Ed.), 288, 1401-1404. http://dx.doi.org/10.1136/bmj.288.6428.1401

[111] Kuusisto, J., Koivisto, K., Mykkänen, L., Helkala, E.L., Vanhanen, M., Hänninen, T., et al. (1997) Association between Features of the Insulin Resistance Syndrome and Alzheimer's Disease Independently of Apolipoprotein E4 Phenotype: Cross Sectional Population Based Study. BMJ, 315, 1045-1049. http://dx.doi.org/10.1136/bmj.315.7115.1045

[112] Liese, A.D., Mayer-Davis, E.J. and Haffner, S.M. (1998) Development of the Multiple Metabolic Syndrome: An Epidemiologic Perspective. Epidemiologic Reviews, 20, 157-172. http://dx.doi.org/10.1093/oxfordjournals.epirev.a017978

[113] Luchsinger, J.A., Tang, M.X., Stern, Y., Shea, S. and Mayeux, R. (2001) Diabetes Mellitus and Risk of Alzheimer's Disease and Dementia with Stroke in a Multiethnic Cohort. American Journal of Epidemiology, 154, 635-641. http://dx.doi.org/10.1093/aje/154.7.635

[114] Peila, R., Rodriguez, B.L. and Launer, L.J. (2002) Type 2 Diabetes, APOE Gene, and the Risk for Dementia and Related Pathologies: The Honolulu-Asia Aging Study. Diabetes, 51, 1256-1262. http://dx.doi.org/10.2337/diabetes.51.4.1256

[115] Eckel, R.H., Grundy, S.M. and Zimmet, P.Z. (2005) The Metabolic Syndrome. The Lancet, 365, 1415-1428. http://dx.doi.org/10.1016/S0140-6736(05)66378-7

[116] Haan, M.N. (2006) Therapy Insight: Type 2 Diabetes Mellitus and the Risk of Late-Onset Alzheimer's Disease. Nature Reviews Neurology, 2, 159-166. http://dx.doi.org/10.1038/ncpneuro0124

[117] McNeill, A.M., Katz, R., Girman, C.J., Rosamond, W.D., Wagenknecht, L.E., Barzilay, J.I., et al. (2006) Metabolic Syndrome and Cardiovascular Disease in Older People: The Cardiovascular Health Study. Journal of the American Geriatrics Society, 54, 1317-1324. http://dx.doi.org/10.1111/j.1532-5415.2006.00862.x

[118] Ay, C., Tengler, T., Vormittag, R., Simanek, R., Dorda, W., Vukovich, T., et al. (2007) Venous ThromboembolismA Manifestation of the Metabolic Syndrome. Haematologica, 92, 374-380. http://dx.doi.org/10.3324/haematol.10828

[119] Jang, M.J., Choi, W.I., Bang, S.M., Lee, T., Kim, Y.K., Ageno, W., et al. (2009) Metabolic Syndrome Is Associated with Venous Thromboembolism in the Korean Population. Arteriosclerosis, Thrombosis, and Vascular Biology, 29, 
311-315. http://dx.doi.org/10.1161/ATVBAHA.109.184085

[120] Monteiro, R. and Azevedo, I. (2010) Chronic Inflammation in Obesity and Metabolic Syndrome. Mediators of Inflammation, 2010, Article ID: 289645. http://dx.doi.org/10.1155/2010/289645

[121] Panza, F., Frisardi, V., Capurso, C., Imbimbo, B.P., Vendemiale, G., Santamato, A., et al. (2010) Metabolic Syndrome and Cognitive Impairment: Current Epidemiology and Possible Underlying Mechanism. Journal of Alzheimer's Disease, 21, 691-724.

[122] Russo, I. (2012) The Prothrombotic Tendency in Metabolic Syndrome: Focus on the Potential Mechanisms Involved in Impaired Haemostasis and Fibrinolytic Balance. Scientifica (Cairo), 2012, Article ID: 525374.

[123] Landin, K., Stigendal, L., Eriksson, E., Krotkewski, M., Risberg, B., Tengborn, L., et al. (1990) Abdominal Obesity Is Associated with an Impaired Fibrinolytic Activity and Elevated Plasminogen Activator Inhibitor-1. Metabolism, 39, 1044-1048. http://dx.doi.org/10.1016/0026-0495(90)90164-8

[124] Juhan-Vague, I. and Vague, P. (1990) Interrelations between Carbohydrates, Lipids, and the Hemostatic Systems in Relation to the Risk of Thrombotic and Cardiovascular Disease. American Journal of Obstetrics \& Gynecology, 163, 313-315. http://dx.doi.org/10.1016/0002-9378(90)90573-P

[125] Juhan-Vague, I. (1996) Haemostatic Parameters and Vascular Risk. Atherosclerosis, 124, S49-S55. http://dx.doi.org/10.1016/0021-9150(96)05857-1

[126] Janand-Delenne, B., Chagnaud, C., Raccah, D., Alessi, M.C., Juhan-Vague, I. and Vague, P. (1998) Visceral Fat as a Main Determinant of Plasminogen Activator Inhibitor 1 Level in Women. International Journal of Obesity and Related Metabolic Disorders, 22, 312-317. http://dx.doi.org/10.1038/sj.ijo.0800585

[127] Mutch, N.J., Wilson, H.M. and Booth, N.A. (2001) Plasminogen Activator Inhibitor-1 and Haemostasis in Obesity. Proceedings of the Nutrition Society, 60, 341-347. http://dx.doi.org/10.1079/PNS200199

[128] Anand, S.S., Yi, Q., Gerstein, H., Lonn, E., Jacobs, R., Vuksan, V., et al. (2003) Relationship of Metabolic Syndrome and Fibrinolytic Dysfunction to Cardiovascular Disease. Circulation, 108, 420-425. http://dx.doi.org/10.1161/01.CIR.0000080884.27358.49

[129] Phelan, M. and Kerins, D.M. (2014) The Role of Plasminogen Activator Inhibitor-1 in the Metabolic Syndrome and Its Regulation. Journal of Food Research, 3, 36-53. http://dx.doi.org/10.5539/jfr.v3n6p36

[130] McGill, J.B., Schneider, D.J., Arfken, C.L., Lucore, C.L. and Sobel, B.E. (1994) Factors Responsible for Impaired Fibrinolysis in Obese Subjects and NIDDM Patients. Diabetes, 43, 104-109. http://dx.doi.org/10.2337/diab.43.1.104

[131] Alessi, M.C. and Juhan Vague, I. (2006) PAI-1 and the Metabolic Syndrome: Links, Causes, and Consequences. Arteriosclerosis, Thrombosis, and Vascular Biology, 26, 2200-2207. http://dx.doi.org/10.1161/01.ATV.0000242905.41404.68

[132] Bodary, P.F. (2007) Links between Adipose Tissue and Thrombosis in the Mouse. Arteriosclerosis, Thrombosis, and Vascular Biology, 27, 2284-2291. http://dx.doi.org/10.1161/ATVBAHA.107.148221

[133] Lijnen, H.R. (2009) Role of Fibrinolysis in Obesity and Thrombosis. Thrombosis Research, 123, S46-S49. http://dx.doi.org/10.1016/S0049-3848(09)70143-4

[134] Juhan-Vague, I., Vague, P., Alessi, M.C., Badier, C., Valadier, J., Aillaud, M.F., et al. (1987) Relationships between Plasma Insulin, Triglyceride, Body Mass Index and Plasminogen Activator Inhibitor 1. Diabetes \& Metabolism, 13, 331-336.

[135] Giltay, E.J., Elbers, J.M., Gooren, L.J., Emeis, J.J., Kooistra, T., Asscheman, H., et al. (1998) Visceral Fat Accumulation Is an Important Determinant of PAI-1 Levels in Young, Nonobese Men and Women: Modulation by Cross-Sex Hormone Administration. Arteriosclerosis, Thrombosis, and Vascular Biology, 18, 1716-1722. http://dx.doi.org/10.1161/01.ATV.18.11.1716

[136] Skurk, T. and Hauner, H. (2004) Obesity and Impaired Fibrinolysis: Role of Adipose Production of Plasminogen Activator Inhibitor-1. International Journal of Obesity and Related Metabolic Disorder, 28, 1357-1364. http://dx.doi.org/10.1038/sj.ijo.0802778

[137] Lijnen, H.R. and Collen, D. (1995) Mechanisms of Physiological Fibrinolysis. Baillière’s Clinical Haematology, 8, 277-290. http://dx.doi.org/10.1016/S0950-3536(05)80268-9

[138] Vague, P., Juhan-Vague, I., Chabert, V., Alessi, M.C. and Atlan, C. (1989) Fat Distribution and Plasminogen Activator Inhibitor Activity in Nondiabetic Obese Women. Metabolism, 38, 913-915. http://dx.doi.org/10.1016/0026-0495(89)90241-2

[139] Kohler, H.P. and Grant, P.J. (2000) Plasminogen-Activator Inhibitor Type 1 and Coronary Artery Disease. The New England Journal of Medicine, 342, 1792-1801. http://dx.doi.org/10.1056/NEJM200006153422406

[140] Sobel, B.E., Taatjes, D.J. and Schneider, D.J. (2003) Intramural Plasminogen Activator Inhibitor Type-1 and Coronary 
Atherosclerosis. Arteriosclerosis, Thrombosis, and Vascular Biology, 23, 1979-1989. http://dx.doi.org/10.1161/01.ATV.0000091250.53231.4D

[141] Sawdey, M.S. and Loskutoff, D.J. (1991) Regulation of Murine Type 1 Plasminogen Activator Inhibitor Gene Expression in Vivo. Tissue Specifity and Induction by Lipopolysaccharide, Tumor Necrosis Factor-Alpha, and Transforming Growth Factor-Beta. Journal of Clinical Investigation, 88, 1346-1353. http://dx.doi.org/10.1172/JCI115440

[142] Loskutoff, D.J. and Samad, F. (1998) The Adipocyte and Hemostatic Balance in Obesity: Studies of PAI-1. Arterioscler Thromb Vascular Biol, 18, 1-6. http://dx.doi.org/10.1161/01.ATV.18.1.1

[143] Lemieux, I., Pascot, A., Prud'homme, D., Alméras, N., Bogaty, P., Nadeau, A., et al. (2001) Elevated C-Reactive Protein; Another Component of the Atherothrombotic Profile of Abdominal Obesity. Arteriosclerosis, Thrombosis, and Vascular Biology, 21, 961-967. http://dx.doi.org/10.1161/01.ATV.21.6.961

[144] Bastelica, D., Morange, P., Berthet, B., Borghi, H., Lacroix, O., Grino, M., et al. (2002) Stromal Cells Are the Main Plasminogen Activator Inhibitor-1-Producing Cells in Human Fat: Evidence of Differences between Visceral and Subcutaneous Deposits. Arteriosclerosis, Thrombosis, and Vascular Biology, 22, 173-178. http://dx.doi.org/10.1161/hq0102.101552

[145] Cigolini, M., Targher, G., Bergamo Andreis, I.A., Tonoli, M., Agostino, G. and De Sandre, G. (1996) Visceral Fat Accumulation and Its Relation to Plasma Hemostatic Factors in Healthy Men. Arteriosclerosis, Thrombosis, and Vascular Biology, 16, 368-374. http://dx.doi.org/10.1161/01.ATV.16.3.368

[146] Alessi, M.C., Peiretti, F., Morange, P., Henry, M., Nalbone, G. and Juhan-Vague, I. (1997) Production of Plasminogen Activator Inhibitor 1 by Human Adipose Tissue: Possible Link between Visceral Fact Accumulation and Vascular Disease. Diabetes, 46, 860-867. http://dx.doi.org/10.2337/diab.46.5.860

[147] Morange, P.E., Alessi, M.C., Verdier, M., Casanova, D., Magalon, G. and Juhan-Vague, I. (1999) PAI-1 Produced ex Vivo by Human Adipose Tissue Is Relevant to PAI-1 Blood Level. Arteriosclerosis, Thrombosis, and Vascular Biology, 19, 1361-1365. http://dx.doi.org/10.1161/01.ATV.19.5.1361

[148] Samad, F., Uysal, K.T., Wiesbrock, S.M., Pandey, M., Hotamisligil, G.S. and Loskutoff, D.J. (1999) Tumor Necrosis Factor Alpha Is a Key Component in the Obesity-Linked Elevation of Plasminogen Activator Inhibitor 1. Proceedings of the National Academy of Sciences of the United States of America, 96, 6902-6907. http://dx.doi.org/10.1073/pnas.96.12.6902

[149] He, G., Bruun, J.M., Lihn, A.S., Pedersen, S.B. and Richelsen, B. (2003) Stimulation of PAI-1 and Adipokines by Glucose in Human Adipose Tissue in Vitro. Biochemical and Biophysical Research Communications, 310, 878-883. http://dx.doi.org/10.1016/j.bbrc.2003.09.091

[150] Crandall, D.L., Quinet, E.M., El Ayachi, S., Hreha, A.L., Leik, C.E., Savio, D.A., et al. (2006) Modulation of Adipose Tissue Development by Pharmacological Inhibition of PAI-1. Arteriosclerosis, Thrombosis, and Vascular Biology, 26, 2209-2215. http://dx.doi.org/10.1161/01.ATV.0000235605.51400.9d

[151] Evans, J.L., Goldfine, I.D., Maddux, B.A. and Grodsky, M. (2003) Are Oxidative Stress-Activated Signaling Pathways Mediators of Insulin Resistance and $\beta$-Cell Dysfunction? Diabetes, 52, 1-8. http://dx.doi.org/10.2337/diabetes.52.1.1

[152] Reddy, V.P., Zhu, X., Perry, G. and Smith, M.A. (2009) Oxidative Stress in Diabetes and Alzheimer's Disease. Journal of Alzheimer's Disease, 16, 763-774.

[153] Neumann, K.F., Rojo, L., Navarrete, L.P., Farías, G., Reyes, P. and Maccioni, R.B. (2008) Insulin Resistance and Alzheimer's Disease: Molecular Link \& Clinical Implications. Current Alzheimer Research, 5, 438-447. http://dx.doi.org/10.2174/156720508785908919

[154] Yates, K.F., Sweat, V., Yau, P.L., Turchiano, M.M. and Convit, A. (2012) Impact of Metabolic Syndrome on Cognition and Brain: A Selective Review of the Literature. Arteriosclerosis, Thrombosis, and Vascular Biology, 32, 20602067. http://dx.doi.org/10.1161/ATVBAHA.112.252759

[155] De Felice, F.G. (2013) Alzheimer’s Disease and Insulin Resistance: Translating Basic Science into Clinical Applications. The Journal of Clinical Investigation, 123, 531-539. http://dx.doi.org/10.1172/JCI64595

[156] Ho, L., Qin, W., Pompl, P.N., Xiang, Z., Wanq, J., Zhao, Z., et al. (2004) Diet-Induced Insulin Resistance Promotes Amyloidosis in a Transgenic Mouse Model of Alzheimer's Disease. The FASEB Journal, 18, 902-904. http://dx.doi.org/10.1096/fj.03-0978fje

[157] De la Monte, S.M. (2009) Insulin Resistance and Alzheimer’s Disease. BMB Reports, 42, 475-481. http://dx.doi.org/10.5483/BMBRep.2009.42.8.475

[158] Craft, S. and Watson, G.S. (2004) Insulin and Neurodegenerative Disease: Shared and Specific Mechanisms. The Lancet Neurology, 3, 169-178. http://dx.doi.org/10.1016/S1474-4422(04)00681-7

[159] Pyörälä, K. (1979) Relationship of Glucose Tolerance and Plasma Insulin to the Incidence of Coronary Heart Disease: Results from Two Population Studies in Finland. Diabetes Care, 2, 131-141. http://dx.doi.org/10.2337/diacare.2.2.131 
[160] Welborn, T.A. and Wearne, K. (1979) Coronary Heart Disease Incidence and Cardiovascular Mortality in Busselton with Reference to Glucose and Insulin Concentrations. Diabetes Care, 2, 154-160. http://dx.doi.org/10.2337/diacare.2.2.154

[161] Ducimetiere, P., Eschwege, E., Papoz, L., Richard, J.L., Claude, J.R. and Rosselin, G. (1980) Relationship of Plasma Insulin Levels to the Incidence of Myocardial Infarction and Coronary Heart Disease Mortality in a Middle-Age Population. Diabetologia, 19, 205-210. http://dx.doi.org/10.1007/BF00275270

[162] Juhan-Vague, I., Thompson, S.G. and Jespersen, J. (1993) Involvement of the Hemostatic System in the Insulin Resistance Syndrome. A Study of 1500 Patients with Angina Pectoris. The ECAT Angina Pectoris Study Group. Arteriosclerosis, Thrombosis, and Vascular Biology, 13, 1865-1873. http://dx.doi.org/10.1161/01.ATV.13.12.1865

[163] Juhan-Vague, I. and Alessi, M.C. (1997) PAI-1, Obesity, Insulin Resistance and Risk of Cardiovascular Events. Journal of Thrombosis and Haemostasis, 78, 656-660.

[164] Bastard, J.P. and Piéroni, L. (1999) Plasma Plasminogen Activator Inhibitor 1, Insulin Resistance and Android Obesity. Biomedicine \& Pharmacotherapy, 53, 455-461. http://dx.doi.org/10.1016/S0753-3322(00)88103-2

[165] Yudkin, J.S. (1999) Abnormalities of Coagulation and Fibrinolysis in Insulin Resistance. Evidence for a Common Antecedent? Diabetes Care, 22, C25-C30.

[166] Bastard, J.P., Piéroni, L. and Hainque, B. (2000) Relationship between Plasma Plasminogen Activator Inhibitor 1 and Insulin Resistance. Diabetes/Metabolism Research and Reviews, 16, 192-201. http://dx.doi.org/10.1002/1520-7560(200005/06)16:3<192::AID-DMRR114>3.0.CO;2-G

[167] Juhan-Vague, I., Alessi, M.C., Mavri, A. and Morange, P.E. (2003) Plasminogen Activator Inhibitor-1, Inflammation, Obesity, Insulin Resistance and Vascular Risk. Journal of Thrombosis and Haemostasis, 1, 1575-1579. http://dx.doi.org/10.1046/j.1538-7836.2003.00279.x

[168] Ott, A., Stolk, R.P., Hofman, A., van Harskamp, F., Grobbee, D.E. and Breteler, M.M. (1996) Association of Diabetes Mellitus and Dementia: The Rotterdam Study. Diabetologia, 39, 1392-1397. http://dx.doi.org/10.1007/s001250050588

[169] Leibson, C.L., Rocca, W.A., Hanson, V.A., Cha, R., Kokmen, E., O’Brien, P.C., et al. (1997) Risk of Dementia among Persons with Diabetes Mellitus: A Population-Based Cohort Study. American Journal of Epidemiology, 145, 301-308. http://dx.doi.org/10.1093/oxfordjournals.aje.a009106

[170] Ott, A., Stolk, R.P., van Harskamp, F., Pols, H.A., Hofman, A. and Breteler, M.M. (1999) Diabetes Mellitus and the Risk of Dementia. The Rotterdam Study. Neurology, 53, 1937-1942. http://dx.doi.org/10.1212/WNL.53.9.1937

[171] Xu, W.L., Qiu, C.X., Wahlin, A., Winbland, B. and Fratiglioni, L. (2004) Diabetes Mellitus and Risk of Dementia in the Kungsholmen Project: A 6 Year Follow-Up Study. Neurology, 63, 1181-1186. http://dx.doi.org/10.1212/01.WNL.0000140291.86406.D1

[172] Vagelatos, N.T. and Eslick, G.D. (2013) Type 2 Diabetes as a Risk Factor for Alzheimer's Disease: The Confounders, Interactions, and Neuropathology Associated with This Relationship. Epidemiologic Reviews, 35, 152-160. http://dx.doi.org/10.1093/epirev/mxs012

[173] Xu, W., Qiu, C., Gatz, M., Pedersen, N.L., Johansson, B. and Fratiglioni, L. (2009) Mid- and Late-Life Diabetes in Relation to the Risk of Dementia: A Population-Based Twin Study. Diabetes, 58, 71-77. http://dx.doi.org/10.2337/db08-0586

[174] Allen, K.V., Frier, B.M. and Strachan, M.W. (2004) The Relationship between Type 2 Diabetes and Cognitive Dysfunction: Longitudinal Studies and Their Methodological Limitations. European Journal of Pharmacology, 490, 169175. http://dx.doi.org/10.1016/j.ejphar.2004.02.054

[175] Arvanitakis, Z., Wilson, R.S., Bienias, J.L., Evans, D.A. and Bennett, D.A. (2004) Diabetes Mellitus and Risk of Alzheimer Disease and Decline in Cognitive Function. Archives of Neurology, 81, 661-666. http://dx.doi.org/10.1001/archneur.61.5.661

[176] Lowe, L.P., Tranel, D., Wallace, R.B. and Welty, T.K. (1994) Type II Diabetes and Cognitive Function: A population-Based Study of Native Americans. Diabetes Care, 17, 891-896. http://dx.doi.org/10.2337/diacare.17.8.891

[177] Strachan, M.W., Deary, I.J., Ewing, F.M. and Frier, B.M. (1997) Is Type II Diabetes Associated with an Increased Risk of Cognitive Dysfunction? A Critical Review of Published Studies. Diabetes Care, 20, 438-445. http://dx.doi.org/10.2337/diacare.20.3.438

[178] Grodstein, F., Chen, J., Wilson, R.S. and Manson, J.E. (2001) Type 2 Diabetes and Cognitive Function in Community-Dwelling Elderly Women. Diabetes Care, 24, 1060-1065. http://dx.doi.org/10.2337/diacare.24.6.1060

[179] Awad, N., Gagnon, M. and Messier, C. (2004) The Relationship between Impaired Glucose Tolerance, Type 2 Diabetes, and Cognitive Function. Journal of Clinical and Experimental Neuropsychology, 26, 1044-1080. http://dx.doi.org/10.1080/13803390490514875

[180] Biessels, G.J. and Kappelle, L.J. (2005) Increased Risk of Alzheimer’s Disease in Type II Diabetes: Insulin Resistance 
of the Brain or Insulin-Induced Amyloid Pathology. Biochemical Society Transactions, 33, 1041-1044. http://dx.doi.org/10.1042/BST0331041

[181] Biessels, G.J., Staekenborg, S., Brunner, E., Brayne, C. and Scheltens, P. (2006) Risk of Dementia in Diabetes Mellitus: A Systematic Review. The Lancet Neurology, 5, 64-74. http://dx.doi.org/10.1016/S1474-4422(05)70284-2

[182] Debling, D., Amelang, M., Hasselbach, P. and Stürmer, T. (2006) Diabetes and Cognitive Function in a Population-Based Study of Elderly Women and Men. Journal of Diabetes and Its Complications, 20, 238-245. http://dx.doi.org/10.1016/j.jdiacomp.2005.06.016

[183] Bruehl, H., Wolf, O.T., Sweat, V., Tirsi, A., Richardson, S. and Convit, A. (2009) Modifiers of Cognitive Function and Brain Structure in Middle-Age and Elderly Individuals with Type 2 Diabetes Mellitus. Brain Research, 1280, 186-194. http://dx.doi.org/10.1016/j.brainres.2009.05.032

[184] Zemva, J. and Schubert, M. (2011) Central Insulin and Insulin-Like Growth Factor-1 Signaling: Implications for Diabetes Associated Dementia. Current Diabetes Reviews, 7, 356-366. http://dx.doi.org/10.2174/157339911797415594

[185] Grant, M.B., Fitzgerald, C., Guay, C. and Lottenberg, R. (1989) Fibrinolytic Capacity Following Stimulation with Desmopressin Acetate in Patients with Diabetes Mellitus. Metabolism, 38, 901-907. http://dx.doi.org/10.1016/0026-0495(89)90239-4

[186] Grossman, H. (2003) Does Diabetes Protect or Provoke Alzheimer’s Disease? Insights into the Pathobiology and Future Treatment of Alzheimer's Disease. CNS Spectrums, 8, 815-823.

[187] Messier, C. (2003) Diabetes, Alzheimer’s Disease and Apolipoprotein Genotype. Experimental Gerontology, 38, 941946. http://dx.doi.org/10.1016/S0531-5565(03)00153-0

[188] Finch, C.E. and Cohen, D.M. (1997) Aging, Metabolism, and Alzheimer Disease: Review and Hypotheses. Experimental Neurology, 143, 82-102. http://dx.doi.org/10.1006/exnr.1996.6339

[189] Pasquier, F., Boulogne, A., Leys, D. and Fontaine, P. (2006) Diabetes Mellitus and Dementia. Diabetes \& Metabolism, 32, 403-414. http://dx.doi.org/10.1016/S1262-3636(07)70298-7

[190] Verdelho, A., Madureira, S., Ferro, J.M., Chabriat, H., Erkinjuntti, T., Fazekas, F., et al. (2007) Differential Impact of Cerebral White Matter Changes, Diabetes, Hipertension and Stroke on Cognitive Performance among Non-Disabled Ederly. The LADIS Study. Journal of Neurology, Neurosurgery \& Psychiatry, 78, 1325-1330. http://dx.doi.org/10.1136/jnnp.2006.110361

[191] Whitmer, R.A. (2007) Type 2 Diabetes and Risk of Cognitive Impairment and Dementia. Current Neurology and Neuroscience Reports, 7, 373-380. http://dx.doi.org/10.1007/s11910-007-0058-7

[192] Li, L. and Hölscher, C. (2007) Common Pathological Processes in Alzheimer Disease and Type 2 Diabetes: A Review. Brain Research Reviews, 56, 384-402. http://dx.doi.org/10.1016/j.brainresrev.2007.09.001

[193] Götz, J., Ittner, L.M. and Lim, Y.A. (2009) Common Features between Diabetes Mellitus and Alzheimer’s Disease. Cellular and Molecular Life Sciences, 66, 1321-1325. http://dx.doi.org/10.1007/s00018-009-9070-1

[194] Roriz-Filho, J.S., Sá-Roriz, T.M., Rosset, I., Camozzato, A.L., Santos, A.C., Chaves, M.L., et al. (2009) (Pre)Diabetes, Brain, Aging and Cognition. Biochimica et Biophysica Acta (BBA), 1792, 432-443. http://dx.doi.org/10.1016/j.bbadis.2008.12.003

[195] Kumar, R., Looi, J.C. and Raphael, B. (2009) Type 2 Diabetes Mellitus, Cognition and Brain in Aging: A Brief Review. Indian Journal of Psychiatry, 51, S35-S38.

[196] Sims-Robinson, C., Kim, B., Rosko, A. and Feldman, E.L. (2010) How does Diabetes Accelerate Alzheimer Disease Pathology? Nature Reviews Neurology, 6, 551-559. http://dx.doi.org/10.1038/nrneurol.2010.130

[197] Szémán, B., Nagy, G., Varga, T., Veres-Székely, A., Sasvari, M., Fitala, D., et al. (2012) [Changes in Cognitive Function in Patients with Diabetes Mellitus]. Orvosi Hetilap, 153, 323-329. (In Hungarian) http://dx.doi.org/10.1556/OH.2012.29319

[198] Steen, E., Terry, B.M., Rivera, E.J., Cannon, J.L., Neely, R.T., Tavares, R., et al. (2005) Impaired Insulin and InsulinLike Growth Factor Expression and Signaling Mechanisms in Alzheimer’s Disease-Is this Type 3 Diabetes? Journal of Alzheimer's Disease, 7, 63-80.

[199] De la Monte, S.M. and Wands, J.R. (2005) Review of Insulin and Insulin-Like Growth Factor Expression, Signaling, and Malfunction in the Central Nervous System: Relevance to Alzheimer's Disease. Journal of Alzheimer's Disease, 7, 45-61.

[200] De la Monte, S.M., Tong, M., Lester-Coll, N., Plater Jr., M. and Wands, J.R. (2006) Therapeutic Rescue of Neuro- degeneration in Experimental Type 3 Diabetes: Relevance to Alzheimer's Disease. Journal of Alzheimer's Disease, 10, 89-109.

[201] De la Monte, S.M. and Wands, J.R. (2008) Alzheimer's Disease Is Type 3 Diabetes-Evidence Reviewed. Journal of Diabetes Science and Technology, 2, 1101-1113. http://dx.doi.org/10.1177/193229680800200619 
[202] Wood, L. and Setter, S.M. (2010) Type 3 Diabetes: Brain Diabetes? U.S. Pharmacist, 35, 36-41.

[203] Akter, K., Lanza, E.A., Martin, S.A., Mironyuk, N., Rua, M. and Raffa, R.B. (2011) Diabetes Mellitus and Alzheimer’s Disease: Shared Pathology and Treatment? British Journal of Clinical Pharmacology, 71, 365-376. http://dx.doi.org/10.1111/j.1365-2125.2010.03830.x

[204] Bláquez, E., Velázquez, E., Hurtado-Carneiro, V. and Ruiz-Albusac, J.M. (2014) Insulin in the Brain: Its Pathophy- siological Implications for States Related with Central Insulin Resistance, Type 2 Diabetes and Alzheimer's Disease. Frontiers in Endocrinology, 5, Article 161. http://dx.doi.org/10.3389/fendo.2014.00161

[205] De la Monte, S.M. (2012) Contributions of Brain Insulin Resistance and Deficiency in Amyloid-Related Neuro- degeneration in Alzheimer's Disease. Drugs, 72, 49-66. http://dx.doi.org/10.2165/11597760-000000000-00000

[206] Clark, T.A., Lee, H.P., Rolston, R.K., Zhu, X., Marlatt, M.W., Castellani, R.J., et al. (2010) Oxidative Stress and Its Implications for Future Treatments and Management of Alzheimer Disease. International Journal of Biomedical Science, 6, 225-227.

[207] Bonda, D.J., Wang, X., Perry, G., Nunomura, A., Tabaton, M., Zhu, X. and Smith, M.A. (2010) Oxidative Stress in Alzheimer Disease: A Possibility for Prevention. Neuropharmacology, 59, 290-294. http://dx.doi.org/10.1016/j.neuropharm.2010.04.005

[208] Saadat, M. (2013) Null Genotypes of Glutathione S-Transferase M1 (GSTM1) and T1 (GSTT1) Polymorphisms Increased Susceptibility to Type 2 Diabetes Mellitus, a Meta-Analysis. Gene, 532, 160-162. http://dx.doi.org/10.1016/j.gene.2013.08.079

[209] Lyon, C.J. and Hsueh, W.A. (2003) Effect of Plasminogen Activator Inhibitor-1 in Diabetes Mellitus and Cardiovascular Disease. American Journal of Medicine, 115, 62S-68S. http://dx.doi.org/10.1016/j.amjmed.2003.08.014

[210] Tsai, A.W., Cushman, M., Rosamond, W.D., Heckbert, S.R., Polak, J.F. and Folsom, A.R. (2002) Cardiovascular Risk Factors and Venous Thromboembolism Incidence: The Longitudinal Investigation of Thromboembolism Etiology. Archives of Internal Medicine, 162, 1182-1189. http://dx.doi.org/10.1001/archinte.162.10.1182

[211] Petrauskiene, V., Falk, M., Waernbaum, I., Norberg, M. and Eriksson, J.W. (2005) The Risk of Venous Thromboembolism Is Markedly Elevated in Patients with Diabetes. Diabetologia, 48, 1017-1021. http://dx.doi.org/10.1007/s00125-005-1715-5

[212] Ageno, W., Becattini, C., Brighton, T., Selby, R. and Kamphuisen, P.W. (2008) Cardiovascular Risk Factors and Venous Thromboembolism: A Meta-Analysis. Circulation, 117, 93-102. http://dx.doi.org/10.1161/CIRCULATIONAHA.107.709204

[213] Stein, P.D., Goldman, J., Matta, F. and Yaekoub, A.Y. (2009) Diabetes Mellitus and Risk of Venous Thromboembolism. The American Journal of the Medical Sciences, 337, 259-264. http://dx.doi.org/10.1097/MAJ.0b013e31818bbb8b

[214] Sobel, B.E., Woodcock-Mitchell, J., Schneider, D.J., Holt, R.E., Marutsuka, K. and Gold, H. (1998) Increased Plasminogen Activator Inhibitor Type 1 in Coronary Artery Atherectomy Specimens from Type 2 Diabetic Compared with Nondiabetic Patients: A Potential Factor Predisposing to Thrombosis and Its Persistence. Circulation, 97, $2213-2221$. http://dx.doi.org/10.1161/01.CIR.97.22.2213

[215] Takada, Y., Urano, T., Watanabe, I., Taminato, A., Yoshimi, T. and Takada, A. (1993) Changes in Fibrinolytic Parameters in Male Patients with Type 2 (Non-Insulin-Dependent) Diabetes Mellitus. Thrombosis Research, 71, 405-415. http://dx.doi.org/10.1016/0049-3848(93)90165-K

[216] Mansfield, M.W., Stickland, M.H. and Grant, P.J. (1995) Plasminogen Activator Inhibitor-1(PAI-1) Promoter Polymorphism and Coronary Artery Disease in Non-Insulin-Dependent Diabetes. Thrombosis and Haemostasis, 74, 10321034.

[217] Opatrny Jr., K., Zemanova, P., Mares, J., Vit, L., Opatrna, S., Sefrna, F., et al. (2002) Fibrinolysis Defect in LongTerm Hemodialysis Patients with Type 2 Diabetes Mellitus and Its Relation to Metabolic Disorders. American Journal of Nephrology, 22, 429-436. http://dx.doi.org/10.1159/000065270

[218] Dunn, E.J., Philippou, H., Ariëns, R.A. and Grant, P.J. (2006) Molecular Mechanisms Involved in the Resistance of Fibrin to Clot Lysis by Plasmin in Subjects with Type 2 Diabetes Mellitus. Diabetologia, 49, 1071-1080. http://dx.doi.org/10.1007/s00125-006-0197-4

[219] Verkleij, C.J.N., Gerdes, V.E.A., de Bruijin, R., Meijers, J.C.M. and Marx, P.F. (2009) The Hemostatic System in Patients with Type 2 Diabetes with and without Cardiovascular Disease. Journal of Thrombosis and Haemostasis, 7, PP-WE-336.

[220] Lemkes, B.A., Hermanides, J., Devries, J.H., Holleman, F., Meijers, J.C. and Hoeskstra, J.B. (2010) Hyperglycemia: A Prothrombotic Factor? Journal of Thrombosis and Haemostasis, 8, 1663-1669. http://dx.doi.org/10.1111/j.1538-7836.2010.03910.x

[221] Aoyagi, T., Wada, T., Kojima, F., Nagai, M., Harada, S. and Takeuchi, T. (1994) Age-Dependent Decreases in Fibrinolytic Enzyme Activities in Serum of Healthy Subjects. Biological and Pharmaceutical Bulletin, 17, 348-351. 
http://dx.doi.org/10.1248/bpb.17.348

[222] Glener, G.G. and Wong, C.W. (1984) Alzheimer’s Disease and Down’s Syndrome: Sharing of a Unique Cerebrovascular Amyloid Fibril Protein. Biochemical and Biophysical Research Communications, 122, 1131-1135. http://dx.doi.org/10.1016/0006-291X(84)91209-9

[223] Masters, C.L., Simms, G., Weinman, N.A., Multhaup, G. and Bevreuther, K. (1985) Amyloid Plaque Core Protein in Alzheimer Disease and Down Syndrome. Proceedings of the National Academy of Sciences of the United States of America, 82, 4245-4249. http://dx.doi.org/10.1073/pnas.82.12.4245

[224] Selkoe, D.J. (1999) Translating Cell Biology into Therapeutic Advances in Alzheimer's Disease. Nature, 399, A23A31. http://dx.doi.org/10.1038/399a023

[225] Selkoe, D.J. (2000) Toward a Comprehensive Theory for Alzheimer's Disease. Hypothesis: Alzheimer's Disease Is Caused by the Cerebral Accumulation and Cytotoxicity of Amyloid Beta-Protein. Annals of the New York Academy of Sciences, 924, 17-25. http://dx.doi.org/10.1111/j.1749-6632.2000.tb05554.X

[226] Selkoe, D.L. (2001) Clearing the Brain’s Amyloid Cobwebs. Neuron, 32, 177-180. http://dx.doi.org/10.1016/S0896-6273(01)00475-5

[227] Iwata, N., Tsubuki, S., Takaki, Y., Shirotani, K., Lu, B., Gerard, N.P., et al. (2001) Metabolic Regulation of Brain A $\beta$ by Neprilysin. Science, 292, 1550-1552. http://dx.doi.org/10.1126/science.1059946

[228] Hardy, J. and Selkoe, D.J. (2002) The Amyloid Hypothesis of Alzheimer's Disease: Progress and Problems on the Road to Therapeutics. Science, 297, 353-356. http://dx.doi.org/10.1126/science.1072994

[229] Delacourte, A. and Defossez, A. (1986) Alzheimer's Disease: Tau Proteins, the Promoting Factors of Microtubule Assembly, Are Major Components of Paired Helical Filaments. Journal of the Neurological Sciences, 76, 173-186. http://dx.doi.org/10.1016/0022-510X(86)90167-X

[230] Kosik, K.S., Joachim, C.L. and Selkoe, D.J. (1986) Microtubule-Associated Protein Tau (Tau) Is a Major Antigenic Component of Paired Helical Filaments in Alzheimer Disease. Proceedings of the National Academy of Sciences of the United States of America, 83, 4044-4048. http://dx.doi.org/10.1073/pnas.83.11.4044

[231] Flament, S., Delacourte, A., Hémon, B. and Défossez, A. (1989) Characterization of Two Pathological Tau Protein, Variants in Alzheimer Brain Cortices. Journal of the Neurological Sciences, 92, 133-141. http://dx.doi.org/10.1016/0022-510X(89)90131-7

[232] Lee, V.M., Balin, B.J., Otvos Jr., L. and Trojanowski, J.Q. (1991) A68: A Major Subunit of Paired Helical Filaments and Derivatized Forms of Normal Tau. Science, 251, 675-678. http://dx.doi.org/10.1126/science.1899488

[233] Kasegawa, M., Morishima-Kawashima, M., Takio, K., Suzuki, M., Titani, K. and Ihara, Y. (1992) Protein Sequence and Mass Spectrometric Analyses of Tau in the Alzheimer's Disease Brain. The Journal of Biological Chemistry, 267, 17047-17054.

[234] Sergeant, N., Bussière, T., Vermersch, P., Lejeune, J.P. and Delacourte, A. (1995) Isoelectric Point Differentiates PHF-Tau from Biopsy-Derived Human Brain Tau Proteins. Neuroreport, 6, 2217-2220. http://dx.doi.org/10.1097/00001756-199511000-00028

[235] Burns, A., Byrne, E.J. and Maurer, K. (2002) Alzheimer’s Disease. The Lancet, 360, 163-165. http://dx.doi.org/10.1016/S0140-6736(02)09420-5

[236] O’Brien, T.D., Butler, P.C., Westermark, P. and Johnson, K.H. (1993) Islet Amyloid Polypeptide: A Review of Its Biology and Potential Roles in the Pathogenesis of Diabetes Mellitus. Veterinary Pathology, 30, 317-332. http://dx.doi.org/10.1177/030098589303000401

[237] O’Brien, T.D., Butler, A.E., Roche, P.C., Johnson, K.H. and Butler, P.C. (1994) Islet Amyloid Polypeptide in Human Insulinomas: Evidence for Intracellular Amyloidogenesis. Diabetes, 43, 329-336. http://dx.doi.org/10.2337/diab.43.2.329

[238] Zhao, H.L., Lai, F.M., Tong, P.C., Zhong, D.R., Yang, D., Tomlinson, B., et al. (2003) Prevalence and Clinicopathological Characteristics of Islet Amyloid in Chinese Patients with Type 2 Diabetes. Diabetes, 52, 2759-2766. http://dx.doi.org/10.2337/diabetes.52.11.2759

[239] Zhao, W.Q. and Townsend, M. (2009) Insulin Resistance and Amyloidogenesis as Common Molecular Foundation for Type 2 Diabetes and Alzheimer’s Disease. Biochimica et Biophysica Acta (BBA), 1792, 482-496. http://dx.doi.org/10.1016/j.bbadis.2008.10.014

[240] Nicolls, M.R. (2004) The Clinical and Biological Relationship between Type 2 Diabetes Mellitus and Alzheimer's Disease. Current Alzheimer Research, 1, 47-54. http://dx.doi.org/10.2174/1567205043480555

[241] Clark, A., Charge, S.B., Badman, M.K., MacArthur, D.A. and de Koning, E.J. (1996) Islet Amyloid Polypeptide: Actions and Role in the Pathogenesis of Diabetes. Biochemical Society Transactions, 24, 594-599. http://dx.doi.org/10.1042/bst0240594 
[242] Clark, A., Charge, S.B., Badman, M.K. and de Koning, E.J. (1966) Islet Amyloid in Type 2 (Non-Insulin-Dependent) Diabetes. APMIS: Acta Pathologica, Microbiologica, et Immunologica Scandinavica, 104, 12-18. http://dx.doi.org/10.1111/j.1699-0463.1996.tb00680.x

[243] Podolsky, S., Leopold, N.A. and Sax, D.S. (1972) Increased Frequency of Diabetes Mellitus in Patients with Huntington's Chorea. The Lancet, 299, 1356-1358. http://dx.doi.org/10.1016/S0140-6736(72)91092-6

[244] Moxley, R.T., Corbett, A.J., Minaker, K.L. and Rowe, J.W. (1984) Whole Body Insulin Resistance in Myotonic Dystrophy. Annals of Neurology, 15, 157-162. http://dx.doi.org/10.1002/ana.410150208

[245] Ristow, M. (2004) Neurodegenerative Disorders Associated with Diabetes Mellitus. Journal of Molecular Medicine, 82, 510-529. http://dx.doi.org/10.1007/s00109-004-0552-1

[246] Smith, M.A., Rottkamp, C.A., Nunomura, A., Raina, A.K. and Perry, G. (2000) Oxidative Stress in Alzheimer's Disease. Biochimica et Biophysica Acta (BBA), 1502, 139-144. http://dx.doi.org/10.1016/S0925-4439(00)00040-5

[247] Markesbery, W.R. (1997) Oxidative Stress Hypothesis in Alzheimer’s Disease. Free Radical Biology and Medicine, 23, 134-147. http://dx.doi.org/10.1016/S0891-5849(96)00629-6

[248] Markesbery, W.R. and Carney, J.M. (1999) Oxidative Alterations in Alzheimer’s Disease. Brain Pathology, 9, $133-146$. http://dx.doi.org/10.1111/j.1750-3639.1999.tb00215.x

[249] Vulin, A.I. and Stanley, F.M. (2004) Oxidative Stress Activates the Plasminogen Activator Inhibitor Type 1 (PAI-1) Promoter through an AP-1 Response Element and Cooperates with Insulin for Additive Effects on PAI-1 Transcription. The Journal of Biological Chemistry, 279, 25172-25178. http://dx.doi.org/10.1074/jbc.M403184200

[250] Shibata, M., Yamada, S., Kumar, S.R., Calero, M., Banding, J., Frangione, B., et al. (2000) Clearance of Alzheimer's Amyloid- $\beta_{1-40}$ Peptide from Brain by LDL Receptor-Related Protein-1 at the Blood-Brain Barrier. The Journal of Clinical Investigation, 106, 1480-1499. http://dx.doi.org/10.1172/JCI10498

[251] Liu, R.M., van Groen, T., Katre, A., Cao, D., Kadisha, I., Ballinger, C., et al. (2011) Knockout of Plasminogen Activator Inhibitor 1 Gene Reduces Amyloid Beta Peptide Burden in a Mouse Model of Alzheimer's Disease. Neuro- biology of Aging, 32, 1079-1089. http://dx.doi.org/10.1016/j.neurobiolaging.2009.06.003

[252] Jain, A., Mårtensson, J., Stole, E., Auld, P.A. and Meister, A. (1991) Glutathione Deficiency Leads to Mitochondrial Damage in Brain. Proceedings of the National Academy of Sciences of the United States of America, 88, 1913-1917. http://dx.doi.org/10.1073/pnas.88.5.1913

[253] Mizui, T., Kinouchi, H. and Chan, P.H. (1992) Depletion of Brain Glutathione by Buthionine Sulfoximine Enhances Cerebral Ischemic Injury in Rats. American Journal of Physiology, 262, H313-H317.

[254] Fiore, G., Baraldi, A., Gambarotta, G.C., Franco, A. and Liberati, C. (1991) Inhibition of Plasminogen Activator (PAI-1) by Sulodexide in Post-Thrombophlebitic Patients. Journal Of Drug Development, 3, 173-178.

[255] Mannarino, E., Pasqualini, L., Ciuffetti, G. and Lombardini, R. (1992) Effect of Oral Administration of Sulodexide on Fibrinolysis and Plasma Viscosity: A Pilot Study. Drug Investigation, 4, 346-350. http://dx.doi.org/10.1007/BF03259415

[256] Mauro, M., Palmieri, G.C., Palazzini, E., Barbanti, M., Calanni, R.F. and Milani, M.R. (1993) Pharmacodynamic Effects of Single and Repeated Doses of Oral Sulodexide in Healthy Volunteers. A Placebo-Controlled Study with an Enteric-Coated Formulation. Current Medical Research and Opinion, 13, 87-95. http://dx.doi.org/10.1185/03007999309111537

[257] Wu, Q. and Zhao, Z. (2002) Inhibition of PAI-1: A New Anti-Thrombotic Approach. Current Drug Target-Cardiovascular \& Hematological Disorders, 2, 27-42. http://dx.doi.org/10.2174/1568006023337727

[258] Lasierra-Cirujeda, J. and Coronel Granado, P. (2006) A Study on the Safety, Efficacy, and Efficiency of Sulodexide Compared with Acenocoumarol in Secondary Prophylaxis in Patients with Deep Venous Thrombosis. Angiology, 57, 53-64. http://dx.doi.org/10.1177/000331970605700108

[259] Lasierra-Cirujeda, J., Aza, M.J. and Aza, M.M. (2016) Sulodexide and Alzheimer's Disease: A Preliminary Prospective Study. World Journal of Cardiovascular Diseases, 6, 54-71. http://dx.doi.org/10.4236/wjcd.2016.62007

[260] Cale, J.M. and Lawrence, D.A. (2007) Structure-Function Relationships of Plasminogen Activator Inhibitor-1 and Its Potential as a Therapeutic Agent. Current Drug Targets, 8, 971-981. http://dx.doi.org/10.2174/138945007781662337

[261] Vaughan, D.E., De Taeye, B.M. and Eren, M. (2007) PAI-1 Antagonists: Predictable Indications and Unconventional Applications. Current Drug Targets, 8, 962-970. http://dx.doi.org/10.2174/138945007781662364

[262] Brown, N.J. (2010) Review: Therapeutic Potential of Plasminogen Activator Inhibitor-1 Inhibitors. Therapeutic Advances in Cardiovascular Disease, 4, 315-324. http://dx.doi.org/10.1177/1753944710379126

[263] Vaughan, D.E. (2011) PAI-1 Antagonists: The Promise and the Peril. Transactions of the American Clinical and Climatological Association, 122, 312-325.

[264] Kutz, S.M., Higgins, C.E. and Higgins, P.J. (2012) Novel Combinatorial Therapeutic Targeting of PAI-1 (SERPINE1) 
Gene Expression in Alzheimer's Disease. Molecular Medicine \& Therapeutics, 1, 106-110. http://dx.doi.org/10.4172/2324-8769.1000106

[265] Ban, T.A., Morey, L.C., Aguglia, E., Bastita, R., Campanella, G., Conti, L., et al. (1991) Glycosaminoglycan Polysulfate in the Treatment of Old Age Dementias. Progress in Neuro-Psychopharmacology \& Biological Psychiatry, 15, 323-342. http://dx.doi.org/10.1016/0278-5846(91)90064-8

[266] Ban, T.A., Morey, L.C., Fjetland, O.K., Rengo, F., Ferrara, N., Agnetti, V., et al. (1992) Early Manifestations of Dementing Illness: Treatment with Glycosaminoglycan Polysulfate. Progress in Neuro-Psychopharmacology \& Biological Psychiatry, 16, 661-676. http://dx.doi.org/10.1016/0278-5846(92)90023-8

[267] Lasierra-Cirujeda, J., Coronel, P., Aza, M.J. and Gimeno, M. (2010) Use of Sulodexide in Patients with Peripheral Vascular Disease. Journal of Blood Medicine, 1, 105-115. http://dx.doi.org/10.2147/JBM.S10558

[268] Pocemich, C.B., La Fontaine, M. and Butterfield, D.A. (2000) In Vivo Glutathione Elevation Protects against Hydroxyl Free Radical-Induced Protein Oxidation in Rat Brain. Neurochemistry International, 36, 185-191. http://dx.doi.org/10.1016/S0197-0186(99)00126-6

[269] Martina, V., Bruno, G.A., Zumpano, E., Origlia, C., Quaranta, L. and Pescarmona, G.P. (2001) Administration of Glutathione in Patients with Type 2 Diabetes Mellitus Increases the Platelet Constitutive Nitric Oxide Synthase Activity and Reduces PAI-1. Journal of Endocrinological Investigation, 24, 37-41. http://dx.doi.org/10.1007/BF03343806

[270] Dringen, R., Pfeiffer, B. and Hamprecht, B. (1999) Synthesis of the Antioxidant Glutathione in Neurons: Supply by Astrocytes of CysGly as Precursor for Neuronal Glutathione. The Journal of Neuroscience, 19, 562-569.

[271] Reid, M. and Jahoor, F. (2001) Glutathione in Disease. Current Opinion in Clinical Nutrition \& Metabolic Care, 4, 6571. http://dx.doi.org/10.1097/00075197-200101000-00012

[272] Rodriguez-Martinez, M.A. and Ruiz-Torres, A. (1992) Homeostasis between Lipid Peroxidation and Antioxidant Enzyme Activities in Healthy Human Aging. Mechanisms of Ageing and Development, 66, 213-222. http://dx.doi.org/10.1016/0047-6374(92)90137-3

[273] Klapcinska, B., Derejczyk, J., Wieczorowska-Tobis, K., Sobczak, A., Sadowska-Krepa, E. and Danch, A. (2000) Antioxidant Defense in Centenarians (a Preliminary Study). Acta Biochimica Polonica, 47, 281-292.

[274] Mari, D., Mannucci, P.M., Coppola, R., Bottasso, B., Bauer, K.A. and Rosenberg, R.D. (1995) Hypercoagulability in Centenarians: The Paradox of Successful Aging. Blood, 85, 3144-3149.

\section{List of Abbreviations}

$\mathrm{A} \beta$ : Amyloid beta peptides

A $\beta$ PP/PS1: Amyloid- $\beta$ protein precursor/presenilin-1

AD: Alzheimer's disease

APOE: Apolipoproteina E

BSO: Buthionine sulfoximine

GSH: Glutathione = gamma-glutamyl-cysteinyl-glycine

HDL: High Density Lipoproteins

IAPP: Islet amyloid polypeptide

IR: Insulin Resistance

LDL: Low Density Lipoproteins

MS: Metabolic Syndrome

PAI-1: Plasminogen activator inhibitor

PD: Parkinson disease

ROS: Reactive oxygen species

TBHQ: Tert-Butyl Hydroquinone

t-PA: Tissue plasminogen activator

TED: Thromboembolic disease

T2DM: Type 2 Diabetes Mellitus 